\title{
A THERMODYNAMIC MODEL FOR HYDROUS SILICATE MELTS ${ }^{1}$
}

\author{
LYNN SILVER AND EDWARD STOLPER
}

Division of Geological and Planetary Sciences, California Institute of Technology, Pasadena, CA 91125

\section{ABSTRACT}

A simple thermodynamic model describing hydrous silicate melts has been applied to the systems albite-, diopside-, and silica- $\mathrm{H}_{2} \mathrm{O}$. The model is based on the assumption of ideal mixing of hydroxyl groups, $\mathrm{H}_{2} \mathrm{O}$ molecules, and oxygens in the melt. Calculated and experimentally determined freezing-point depressions and $\mathrm{H}_{2} \mathrm{O}$ solubilities for these systems are in agreement over substantial pressure and temperature intervals. The success of this model in accounting for observed phase equilibria of hydrous systems and its consistency with spectroscopic measurements of the concentrations of H-bearing species in glasses suggests that it accurately represents the interaction between $\mathrm{H}_{2} \mathrm{O}$ and silicate melts at a molecular level.

\section{INTRODUCTION}

Thermodynamic models of water-bearing silicate melts have been widely applied both to provide a framework for understanding the observed variations in chemical and physical properties of melts with varying water content and to provide a way to quantitatively model phase equilibria relevant to petrological systems. Thus Burnham (1975), for example, attempted to infer the solubility mechanism of water in silicate melts from an equation of state for hydrous albitic melts and related this to observed variations in physical properties with water content. Spera (1974) applied another model of the mixing properties of hydrous silicate melts to predict water solubilities in melts in the upper mantle and tried to explain the stabilization of the low velocity zone. Thermodynamic models provide powerful tools for addressing these and other petrologically important issues.

Thermodynamic models of hydrous silicate melts fall into two broad categories. The first approach is largely macroscopic and empirical. For example, Burnham and Davis (1971) fitted data on the partial molar volumes of water and albite components in hydrous albitic melt to third-order polynomials in $\mathrm{P}$ and $\mathrm{T}$ with 10 constants. By appropriate manipulations of this expression, in which phase equilibrium data were used as reference points, Burnham and Davis (1974) developed

${ }^{1}$ Manuscript received July 9, 1984; revised December 11, 1984.

[Journal of Geology, 1985, vol. 93, p. 161-178] (C) 1985 by The University of Chicago. All rights reserved.

0022-1376/85/9302-008\$1.00 an activity-composition relationship for this system. This expression, in somewhat modified form, was applied to hydrous diopside melts by Eggler and Burnham (1984). Spera (1974) used solubility data to constrain activity-composition relations for water-bearing silicate melts using the standard formulae for asymmetric regular solutions. Nicholls (1980) followed a similar approach using a symmetric regular solution formulation. These formulations are extremely valuable for predicting phase equilibria in hydrous systems and have been successfully applied to a wide range of interesting geological problems. The expressions for activity versus composition in these cases, however, have no microscopic significance. They are empirical, in some cases arbitrary, and they contain no explicit information on the molecular level interactions leading to the observed activity-composition relations. There is no inherent problem with this, because thermodynamics need not consider the nature of molecular interactions within the substance of interest; it suffices to have accurate empirical information on the substance's equation of state. However, information about molecular level processes and equilibria can be obtained only with difficulty, if at all, from such descriptions of the properties of systems as complex as liquid silicates.

The second approach to the thermodynamics of hydrous silicate melts is better suited to constraining the nature of their molecular level structures and homogeneous equilibria. In this treatment, first applied to hydrous silicate melts by Wasserburg (1957) and further developed by Shaw $(1964,1968)$ and Stolper $(1982 a)$, statistical thermodynamics is used, 
given certain assumptions about species and their interactions on a molecular level, to generate expressions for the thermodynamic properties of silicate melts. Although these models are simple, they provide a basis for understanding the thermodynamic properties of silicate melts and solubility mechanisms of water on a molecular level. These models specify the functional form of the activitycomposition relationship based on the assumed molecular level interactions. To the extent that these thermodynamic functions can explain macroscopic phenomena (e.g., solubility relations, freezing-point depressions), these models may be judged acceptable and hence represent possible descriptions of melt structure.

In this paper, we apply the model of Stolper (1982a) to calculating phase equilibria in the systems albite-, diopside-, and silica$\mathrm{H}_{2} \mathrm{O}$. We show that the activity-composition relations that arise from our simple model of interactions between molecules of water, hydroxyl groups, and oxygen atoms in melts in these systems are consistent with available experimentally determined phase equilibria. When coupled with the fact that this model also predicts concentrations of each of these species that are broadly consistent with a growing body of spectroscopic data, we conclude that this model provides a useful tool both for understanding the species level properties of hydrous silicate melts and for modelling their macroscopic phase equilibria.

\section{THE MODEL}

We model hydrous silicate melts as ideal mixtures of water molecules, hydroxyl groups, and oxygen atoms. These species interact through the following homogeneous equilibrium:

$$
\begin{gathered}
\mathrm{H}_{2} \mathrm{O} \text {,molecular (melt) } \\
+\mathrm{O} \text { (melt) }=2 \mathrm{OH} \text { (melt) }
\end{gathered}
$$

where $\mathrm{O}=$ an oxygen atom, $\mathrm{OH}=\mathrm{a}$ hydroxyl group, and $\mathrm{H}_{2} \mathrm{O}$, molecular $=$ a water molecule in the melt. Associated with this reaction is an equilibrium constant,

$$
\mathrm{K}_{1}=\frac{\left(\mathrm{a}_{\mathrm{OH}}^{\mathrm{m}}\right)^{2}}{\left(\mathrm{a}_{\mathrm{O}}^{\mathrm{m}}\right)\left(\mathrm{a}_{\mathrm{H}_{2} \mathrm{O}, \mathrm{mol}}^{\mathrm{m}}\right)}
$$

where $\mathrm{a}_{\mathrm{OH}}^{\mathrm{m}}, \mathrm{a}_{\mathrm{H}_{2} \mathrm{O}, \mathrm{mol}}$, and $\mathrm{a}_{\mathrm{O}}^{\mathrm{m}}$ refer to the activities of hydroxyl groups, molecular water and "free" oxygens (in the sense that they are not associated with hydrogens) in the melt. The melt is modeled as a mixture of $n_{O}$ "free" oxygens, $\mathrm{n}_{\mathrm{OH}}$ hydroxyl groups and $\mathrm{n}_{\mathrm{H}_{2} \mathrm{O} \text {, mol }}$ water molecules over $\Sigma \mathbf{n}=\mathrm{n}_{\mathrm{O}}+\mathrm{n}_{\mathrm{OH}}+$ $\mathrm{n}_{\mathrm{H}_{2} \mathrm{O} \text {,mol }}$ sites. Because the mixture is ideal and all "free" oxygens are taken to be energetically equivalent and indistinguishable, the activity of each species is equal to its mole fraction:

$$
\begin{gathered}
a_{\mathrm{H}_{2} \mathrm{O}, \mathrm{mol}}^{m}=X_{\mathrm{H}_{2} \mathrm{O}, \mathrm{mol}}^{m}=\frac{\mathrm{n}_{\mathrm{H}_{2} \mathrm{O}, \mathrm{mol}}}{\Sigma \mathrm{n}} \\
\mathrm{a}_{\mathrm{OH}}^{\mathrm{m}}=X_{\mathrm{OH}}^{m}=\frac{n_{\mathrm{OH}}}{\Sigma \mathrm{n}} \\
a_{\mathrm{O}}^{m}=X_{\mathrm{O}}^{m}=\frac{n_{\mathrm{O}}}{\Sigma \mathrm{n}}
\end{gathered}
$$

When $\mathrm{N}_{1}$ moles of $\mathrm{H}_{2} \mathrm{O}$ are mixed with $\mathrm{N}_{2}$ moles of anhydrous silicate that contributes $\mathrm{r}$ oxygens per mole of silicate (e.g., $r=2$ for $\mathrm{SiO}_{2}, \mathrm{r}=8$ for $\mathrm{NaAlSi}_{3} \mathrm{O}_{8}$ ), they react until equilibrium as given by reaction (1) is achieved. The relationship between the reactants and products is described by:

$$
\begin{gathered}
\mathrm{n}_{\mathrm{O}}=\mathrm{rN}_{2}-\frac{1}{2} \mathrm{n}_{\mathrm{OH}} \\
\mathrm{n}_{\mathrm{H}_{2} \mathrm{O}, \mathrm{mol}}=\mathrm{N}_{1}-\frac{1}{2} \mathrm{n}_{\mathrm{OH}}
\end{gathered}
$$

Substituting these expressions into (2) and (3), we obtain the following equations for the mole fractions of each species, given values for the bulk composition of the system (i.e., $\mathrm{N}_{1}, \mathrm{rN}_{2}$ ) and $\mathrm{K}_{1}$ :

$$
\begin{gathered}
X_{O H}^{m}=\left\{\frac{1}{2}-\left[\frac{1}{4}-\left(\frac{K_{1}-4}{K_{1}}\right)\right.\right. \\
\left.\left.\left(X_{B}-X_{B}^{2}\right)\right]^{1 / 2}\right\} /\left(\frac{K_{1}-4}{2 K_{1}}\right) \\
X_{H_{2} O, m o l}^{m}=X_{B}-\frac{1}{2} X_{O H}^{m} \\
=X_{B}-\left\{\frac{1}{2}-\left[\frac{1}{4}-\left(\frac{K_{1}-4}{K_{1}}\right)\right.\right. \\
\left.\left.\left(X_{B}-X_{B}^{2}\right)\right]^{1 / 2}\right\} /\left(\frac{K_{1}-4}{K_{1}}\right)
\end{gathered}
$$




$$
\begin{aligned}
X_{\mathrm{O}}^{\mathrm{m}}= & 1-2 \mathrm{X}_{\mathrm{B}}+\mathrm{X}_{\mathrm{H}_{2} \mathrm{O}, \mathrm{mol}}^{\mathrm{m}} \\
= & 1-\mathrm{X}_{\mathrm{B}}-\left\{\frac{1}{2}-\left[\frac{1}{4}-\left(\frac{\mathrm{K}_{1}-4}{\mathrm{~K}_{1}}\right)\right.\right. \\
& \left.\left.\left(\mathrm{X}_{\mathrm{B}}-\mathrm{X}_{\mathrm{B}}^{2}\right)\right]^{1 / 2}\right\} /\left(\frac{\mathrm{K}_{1}-4}{\mathrm{~K}_{1}}\right)
\end{aligned}
$$

where $X_{B}=N_{1} /\left(N_{1}+r N_{2}\right)$.

$X_{B}$ is the variable that we use to express the bulk composition of the system; it is the mole fraction of total water in the melt where the anhydrous component is taken as having only one oxygen. In other words, $X_{B}=1 / 9$ when the melt consists of one mole of $\mathrm{H}_{2} \mathrm{O}$ and one mole of $\mathrm{NaAlSi}_{3} \mathrm{O}_{8} . \mathrm{X}_{\mathrm{B}}$ can be calculated for a complex melt composition with a known water content using the following equation:

$$
\mathrm{X}_{\mathrm{B}}=\frac{\mathrm{wt} \% \mathrm{H}_{2} \mathrm{O} / 18.015}{-\begin{array}{c}
\text { wt } \left.\% \mathrm{H}_{2} \mathrm{O} / 18.015\right)+(100 \\
\left.-\mathrm{wt} \% \mathrm{H}_{2} \mathrm{O}\right) /(\text { molecular weight of } \\
\text { anhydrous silicate per oxygen })
\end{array}}
$$

The molecular weight of the silicate per oxygen refers to the molecular weight of anhydrous melt on a single oxygen basis and would, for example, be 32.78 for albite. Equations (5.1-5.3) constitute the activitycomposition relationships for hydrous silicate melts given by our model of molecular level interactions. Note again that these equations are based on the approximation that all free oxygens are equivalent and equally reactive.

$\mathrm{K}_{1}$ can be determined directly from infrared spectroscopic measurements on hydrous silicate glasses (Stolper, 1982b) by which the concentrations of hydroxyl groups and molecules of water can be precisely determined (assuming that the speciation in a glass reflects that of the melt from which it was quenched). However, for the purposes of applying this model without bias, we will determine the value of $K_{1}$ for each system that best fits the phase equilibrium data without reference to $K_{1}$ values determined by spectroscopic methods. The degree to which these two means of determining $\mathrm{K}_{1}$ produce similar values provides an independent check of the validity of our model. In our treatment, $K_{1}$ is assumed to be independent of $T, P$, and total water content, but is allowed to vary with the anhydrous melt composition. Based on spectroscopic measurements, this appears to be valid to first order, although $K_{1}$ does appear to be weakly dependent on total water content (Stolper 1982a, 1982b), temperature (Stolper et al. 1983), and perhaps pressure (Nogami and Tomozawa 1984).

The solubility of water in silicate melts, i.e., the concentration of water dissolved in the melt when it is in equilibrium with water vapor, is readily modeled given the activitycomposition relations of equations (5.1-5.3). The equilibrium between the vapor and the dissolved $\mathrm{H}_{2} \mathrm{O}$ in the melt is described by:

$$
\mathrm{H}_{2} \mathrm{O} \text { (vapor) }=\mathrm{H}_{2} \mathrm{O} \text {, molecular (melt) }
$$

This reaction has an equilibrium constant,

$$
\mathrm{K}_{2}=\frac{\mathrm{a}_{\mathrm{H}_{2} \mathrm{O}, \mathrm{mol}}^{\mathrm{m}}}{\mathrm{a}_{\mathrm{H}_{2} \mathrm{O}}^{\mathrm{v}}}=\frac{\mathrm{X}_{\mathrm{H}_{2} \mathrm{O}, \mathrm{mol}}^{\mathrm{m}}}{\mathrm{f}_{\mathrm{H}_{2} \mathrm{O}} / \mathrm{f}_{\mathrm{H}_{2} \mathrm{O}}^{\mathrm{o}}}
$$

The standard state fugacity for the vapor $\left(\mathrm{f}_{\mathrm{H}_{2} \mathrm{O}}^{\mathrm{O}}\right.$ ) is defined as that of pure water at $\mathrm{P}$ and $\mathrm{T}$; $\mathrm{f}_{\mathrm{H}_{2} \mathrm{O}}$ is the fugacity of water in the vapor. The activity of water in the vapor at any $P$ and $\mathrm{T}, \mathrm{a}_{\mathrm{H}_{2} \mathrm{O}}^{\mathrm{O}}$, is thus equal to one if the vapor is pure water and less than one if the vapor has other constituents in addition to water. Equation (5.2) can be rearranged to give total water content in terms of $\mathrm{X}_{\mathrm{H}_{2} \mathrm{O} \text {, mol }}^{\mathrm{m}}$ :

$$
\begin{aligned}
\mathrm{X}_{\mathrm{B}}= & \mathrm{X}_{\mathrm{H}_{2} \mathrm{O}, \mathrm{mol}}+\frac{1}{4}\left\{-\mathrm{K}_{1} \mathrm{X}_{\mathrm{H}_{2} \mathrm{O}, \mathrm{mol}}\right. \\
& +\left[\left(\mathrm{K}_{1} \mathrm{X}_{\mathrm{H}_{2} \mathrm{O}, \mathrm{mol}}\right)^{2}-4 \mathrm{~K}_{1} \mathrm{X}_{\mathrm{H}_{2} \mathrm{O}, \mathrm{mol}}^{2}\right. \\
& \left.\left.+4 \mathrm{~K}_{1} \mathrm{X}_{\mathrm{H}_{2} \mathrm{O}, \mathrm{mol}}\right]^{1 / 2}\right\}
\end{aligned}
$$

If $\mathrm{K}_{1}, \mathrm{~K}_{2}$, and $\mathrm{f}_{\mathrm{H}_{2} \mathrm{O}}$ are known, we can calculate total solubility:

$$
\begin{aligned}
\mathrm{X}_{\mathrm{B}}= & \mathrm{K}_{2} \mathrm{a}_{\mathrm{H}_{2} \mathrm{O}}^{\mathrm{v}}+\frac{1}{4}\left\{-\mathrm{K}_{1} \mathrm{~K}_{2} \mathrm{a}_{\mathrm{H}_{2} \mathrm{O}}^{\mathrm{v}}\right. \\
& +\left[\left(\mathrm{K}_{1} \mathrm{~K}_{2} \mathrm{a}_{\mathrm{H}_{2} \mathrm{O}}^{\mathrm{v}}\right)^{2}-4 \mathrm{~K}_{1}\left(\mathrm{~K}_{2} \mathrm{a}_{\mathrm{H}_{2} \mathrm{O}}^{\mathrm{v}}\right)^{2}\right. \\
& \left.\left.+4 \mathrm{~K}_{1} \mathrm{~K}_{2} \mathrm{a}_{\mathrm{H}_{2} \mathrm{O}}^{\mathrm{v}}\right]^{1 / 2}\right\}
\end{aligned}
$$


$X_{B}$ can be converted to weight percent $\mathrm{H}_{2} \mathrm{O}$ by the following relation:

$$
\text { wt } \% \mathrm{H}_{2} \mathrm{O}=\frac{\left(\mathrm{X}_{\mathrm{B}}\right)(18.015)}{\begin{array}{c}
\left(\mathrm{X}_{\mathrm{B}}\right)(18.015)+\left(1-\mathrm{X}_{\mathrm{B}}\right) \\
(\text { molecular weight of } \\
\text { anhydrous silicate per oxygen })
\end{array}}
$$

As demonstrated by Stolper (1982a), this model successfully predicts the observed linear relationship between $\mathrm{f}_{\mathrm{H}_{2} \mathrm{O}}$ and $\left(\mathrm{X}_{\mathrm{B}}\right)^{2}$ for melts at low total water contents, provided that $\mathrm{K}_{1}$ has a value similar to the $\sim 0.2 \mathrm{de}$ rived spectroscopically. We will now show that our model can also adequately reproduce the experimentally determined hydrous melting relations and water solubilities as functions of $\mathbf{P}$ for three silicate- $\mathrm{H}_{2} \mathrm{O}$ systems.

\section{FREEZING POINT DEPRESSION}

Our first goal is to calculate the depression of the liquidus of a silicate with the addition of water (e.g., curve A-B in fig. 1). At any P and $\mathrm{T}$, the activity of the anhydrous component in a binary silicate- $\mathrm{H}_{2} \mathrm{O}$ liquid in equilibrium with a crystalline silicate with the composition of the anhydrous component (e.g., the activity of albite in a hydrous albite melt in equilibrium with crystalline albite) is given by:

$$
a_{\text {silicate }}^{\mathrm{m}}=\exp \left[\frac{1}{\mathrm{RT}} \int_{\mathrm{T}_{\mathrm{m}}^{\mathrm{p}}}^{\mathrm{T}} \Delta \overline{\mathrm{S}}_{\mathrm{f}}(\mathrm{T}, \mathrm{P}) \mathrm{dT}\right]
$$

$\Delta \overline{\mathrm{S}}_{\mathrm{f}}(\mathrm{T}, \mathrm{P})$ is the molar entropy of fusion of the anhydrous crystalline silicate. $T_{m}^{P}$ is the anhydrous melting temperature of the crystalline silicate at $P$ (e.g., point $A$ in fig. 1). The standard states of the anhydrous crystal and liquid components are taken to be anhydrous crystal and liquid at $\mathrm{P}$ and $\mathrm{T}$ (e.g., the activities of albite in pure crystalline and liquid albite are unity at all $\mathrm{T}$ and $\mathrm{P}$ ).

For our model, $a_{\text {silicate }}^{m}=\left(a_{O}^{m}\right)^{r}=\left(X_{O}^{m}\right)^{r}$ where, as described earlier, $r$ is equal to the number of oxygen atoms per gram-formulaunit of anhydrous silicate. Therefore, equation (12) becomes:

$$
X_{O}=\exp \left[\frac{1}{r R T} \int_{T_{m}^{p}}^{T} \Delta \bar{S}_{f}(T, P) d T\right]
$$

This factor of $r$ can be avoided if the anhydrous silicate component is always given by a

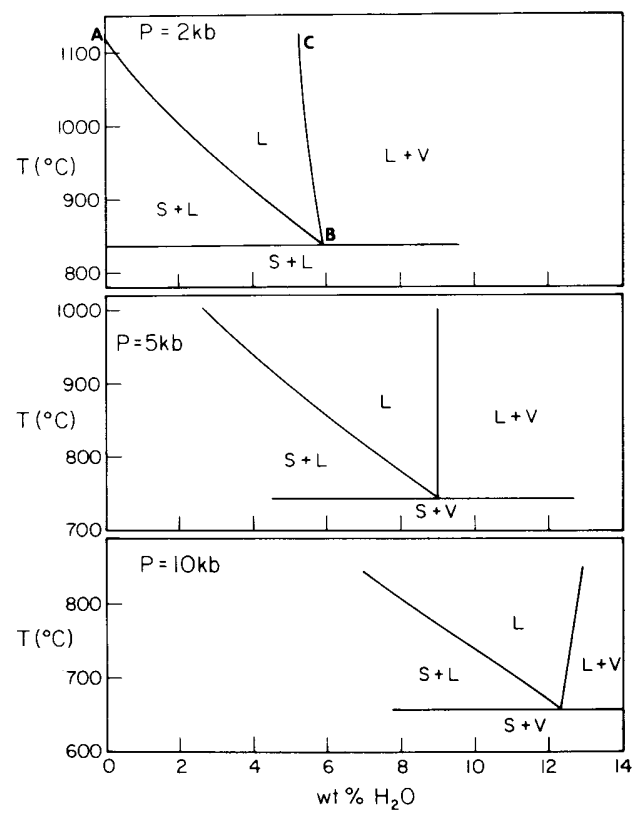

FIG. 1.-Calculated isobaric T-X sections for the water-poor region of the albite- $\mathrm{H}_{2} \mathrm{O}$ system at $\mathrm{P}=$ 2,5 , and $10 \mathrm{~kb}$. Point $\mathrm{A}$ is the anhydrous melting temperature of albite at $P=2 \mathrm{~kb}$. Curve $A-B$ is the liquidus calculated for $P=2 \mathrm{~kb}$ and $\mathrm{K}_{1}=0.17$. Curve B-C is the vapor-saturation boundary calculated using equations (24) and (10). See text for details.

formula unit with only one oxygen. Equation (5.3) can be rearranged to give:

$$
\begin{aligned}
X_{B}=1 & -X_{O}+\frac{1}{4}\left\{K_{1} X_{O}-\left[\left(K_{1} X_{O}\right)^{2}\right.\right. \\
& \left.\left.+4 K_{1} X_{O}-4 K_{1} X_{O}^{2}\right]^{1 / 2}\right\}
\end{aligned}
$$

By substituting equation (13) into equation (14), we obtain an equation for the liquidus in a binary silicate- $\mathrm{H}_{2} \mathrm{O}$ system; i.e., the amount of water dissolved in a silicate melt in equilibrium with anhydrous silicate crystals as a function of temperature. This calculation requires expressions for $\Delta \overline{\mathrm{S}}_{\mathrm{f}}(\mathrm{T}, \mathrm{P}), \mathrm{T}_{\mathrm{m}}^{\mathrm{P}}(\mathrm{P})$ and for $K_{1}$. The entropies of fusion and the expressions for the dry solidus are available from thermochemical measurements and phase equilibria. The expressions that we used and the sources of the data are given in table $1 . \mathrm{K}_{1}$ can be determined spectroscopically or can be calculated from phase equilibria data as explained below. 


\section{MELT-VAPOR EQUILIBRIUM}

Each liquidus curve shown in figure 1 ultimately intersects the wet solidus, i.e., a temperature is reached at which anhydrous crystal, hydrous liquid and vapor coexist. We will next show how to calculate the variations in temperature and water content of the hydrous melt at the wet solidus with pressure given the activity-composition relationships of our model.

Notice that we write that we can calculate the variations in temperature and water content of the melt at the wet solidus as functions of pressure. Our formulation of the thermodynamics of hydrous silicate melts involves two equilibrium constants, $\mathrm{K}_{1}$ and $\mathrm{K}_{2}$. Values of these must somehow be determined at a reference point before we can carry out the phase equilibrium calculations that are of interest. The most direct way would be to measure the concentrations of the hydroxyl groups and molecular water in a glass quenched rapidly from a melt saturated with vapor at some $P$ and $T$. $K_{1}$ and $K_{2}$ values could be determined from these measurements and then used to carry out the desired calculations. An alternate approach, and the one we have chosen here, is to take a single point on the wet solidus and the solubility of water in the melt at this point as given; this fixes $K_{1}$ and $K_{2}$ at the reference temperature $\left(\mathrm{T}_{\mathrm{r}}\right)$ and pressure $\left(\mathrm{P}_{\mathrm{r}}\right)$ and allows calculations of the remainder of the phase diagram. As explained earlier, our reason for choosing this second approach is that $K_{1}$ and $K_{2}$ determined in this way are independent of any spectroscopic measurements. To the extent that the values determined in this way agree with the spectroscopic measurements, they demonstrate the internal consistency of our model of the thermodynamics of hydrous melts.

The value of $K_{1}$ is calculated in the following way. A point on the wet solidus is taken as known, with values for temperature, pressure and total water solubility given by $T_{r}, P_{r}$ and $X_{B}^{r}$. Solving equation (13) at $T=T_{r}$ and $P$ $=P_{r}$ provides a value for $X_{O}^{r}$ at the reference point. This value and $X_{B}$ can then be substituted into the following expression to obtain $K_{1}$ at the reference point (and at all other $\mathrm{T}$ and $\mathrm{P}$, given our assumption of constant $\left.\mathrm{K}_{1}\right)$ :
$\mathrm{K}_{1}=4\left(1-\mathrm{X}_{\mathrm{B}}-\mathrm{X}_{\mathrm{O}}\right)^{2} / \mathrm{X}_{\mathrm{O}}\left(\mathrm{X}_{\mathrm{O}}-1+2 \mathrm{X}_{\mathrm{B}}\right)$

Assuming that the vapor is pure water (i.e., $\mathrm{a}_{\mathrm{H}, \mathrm{O}}^{\mathrm{A}}=1$ ), we can substitute equation (5.2) into equation (8) to obtain the following equation for $\mathrm{K}_{2}$, at the reference point in terms of $\mathrm{X}_{\mathrm{B}}^{\mathrm{r}}$ and $\mathrm{K}_{\mathrm{I}}$ :

$$
\begin{aligned}
& \mathrm{K}_{2}\left(\mathrm{~T}_{\mathrm{r}}, \mathrm{P}_{\mathrm{r}}\right)=\mathrm{X}_{\mathrm{H}_{2} \mathrm{O}, \mathrm{mol}}^{\mathrm{r}}=\mathrm{X}_{\mathrm{B}}^{\mathrm{r}} \\
& -\left\{\frac{1}{2}-\left[\frac{1}{4}-\left(\frac{\mathrm{K}_{1}-4}{\mathrm{~K}_{1}}\right)\right.\right. \\
& \left.\left.\left(\mathrm{X}_{\mathrm{B}}^{\mathrm{r}}-\left(\mathrm{X}_{\mathrm{B}}^{\mathrm{r}}\right)^{2}\right)^{1 / 2}\right]\right\} /\left(\frac{\mathrm{K}_{1}-4}{\mathrm{~K}_{1}}\right)
\end{aligned}
$$

The reference point in each system was chosen to be midway along the solidus at a point where the solidus and solubility are well constrained. Choosing other points along the solidus and solubility curves as the reference does result in different values for $K_{1}$ and $K_{2}$. Uncertainties in $\mathrm{K}_{1}$ and $\mathrm{K}_{2}$ that result from different choices of reference points do not lead to significant uncertainties in our calculations of phase equilibria.

The variation in $\mathrm{K}_{2}$, and thus water solubility, with pressure and temperature can now be calculated. For all melts saturated with vapor,

$$
\mu_{\mathrm{H}_{2} \mathrm{O}}^{\mathrm{v}}=\mu_{\mathrm{H}_{2} \mathrm{O} \cdot \mathrm{mol}}^{\mathrm{m}}
$$

where $\mu=$ chemical potential, $\mathrm{m}=$ melt phase and $v=$ vapor phase. Expressing the chemical potentials in terms of activities,

$$
\begin{aligned}
\mu_{\mathrm{H}_{2} \mathrm{O}}^{\mathrm{o}, \mathrm{v}}(\mathrm{P}, \mathrm{T}) & +\mathrm{RT} \ln \mathrm{a}_{\mathrm{H}_{2} \mathrm{O}}^{\mathrm{v}}=\mu_{\mathrm{H}_{2} \mathrm{O}, \mathrm{mol}}^{\mathrm{o}, \mathrm{m}}(\mathrm{P}, \mathrm{T}) \\
& +\mathrm{RT} \ln \mathrm{a}_{\mathrm{H}_{2} \mathrm{O}, \mathrm{mol}}^{\mathrm{m}}
\end{aligned}
$$

The standard state for the vapor phase is pure water vapor at $\mathrm{P}$ and $\mathrm{T}$. For molecular water in the melt, the standard state refers to a fictive material at $\mathrm{T}$ and $\mathrm{P}$ with the composition of pure molecular water but with an arrangement of these water molecules similar to that of oxygens in the anhydrous silicate melt (Stolper 1982a). Recalling that $\mathrm{K}_{2}$ is equal to $\left(\mathrm{a}_{\mathrm{H}_{2} \mathrm{O}, \mathrm{mol}}^{\mathrm{m}} / \mathrm{a}_{\mathrm{H}_{2} \mathrm{O}}^{\mathrm{v}}\right)$, we obtain that at $\mathrm{T}=$ $\mathrm{T}_{\mathrm{r}}$ and $\mathrm{P}=\mathrm{P}_{\mathrm{r}}$ : 
TABLE 1

$\Delta \overline{\mathrm{S}}_{\mathrm{f}}(\mathrm{T}, \mathrm{P})$ and $\int_{\mathrm{T}_{\mathrm{m}}^{\mathrm{P}}}^{\mathrm{T}} \Delta \overline{\mathrm{S}}_{\mathrm{f}}(\mathrm{T}, \mathrm{P}) \mathrm{dT}$

Diopside $\left(\mathrm{Ca}_{1.33} \mathrm{Mg}_{1.33} \mathrm{Si}_{2.67} \mathrm{O}_{8}\right)$ : $\begin{aligned} \Delta \overline{\mathrm{S}}_{\mathrm{f}}(\mathrm{T}, \mathrm{P})^{\mathrm{a}}= & \Delta \overline{\mathrm{S}}_{\mathrm{f}}^{\mathrm{o}}\left(\mathrm{T}_{\mathrm{m}}^{\mathrm{o}}, 1\right)-28.163 \ln \left(\mathrm{T}_{\mathrm{m}}^{\mathrm{o}}\right)+3.018\left(10^{-4}\right)\left(\mathrm{T}_{\mathrm{m}}^{\mathrm{o}}\right)+2.0645\left(10^{6}\right) /\left(\mathrm{T}_{\mathrm{m}}^{\mathrm{o}}\right)^{2}-4.635\left(10^{-6}\right)(\mathrm{P}-1)+28.163 \ln (\mathrm{T})-3.018\left(10^{-4}\right) \mathrm{T} \\ & -2.0645\left(10^{6}\right) / \mathrm{T}^{2}\end{aligned}$

$\Delta \overline{\mathrm{S}}_{\mathrm{f}}^{\mathrm{o}}\left(\mathrm{T}_{\mathrm{m}}^{\mathrm{o}}, 1\right)=19.82 \mathrm{cal} / \mathrm{K}$ mole where $\mathrm{T}_{\mathrm{m}}^{\mathrm{o}}=1664 \mathrm{~K}$ at $1 \mathrm{bar}$.

$\int_{T_{m}^{P}}^{\mathrm{T}} \Delta \overline{\mathrm{S}}_{\mathrm{f}}(\mathrm{T}, \mathrm{P}) \mathrm{dT}=\left[\Delta \overline{\mathrm{S}}_{\mathrm{f}}^{\mathrm{o}}\left(\mathrm{T}_{\mathrm{m}}^{\mathrm{o}}, 1\right)-28.163 \ln \left(\mathrm{T}_{\mathrm{m}}^{\mathrm{o}}\right)+3.018\left(10^{-4}\right)\left(\mathrm{T}_{\mathrm{m}}^{\mathrm{o}}\right)+2.0645\left(10^{6}\right) /\left(\mathrm{T}_{\mathrm{m}}^{\mathrm{o}}\right)^{2}-4.635\left(10^{-6}\right)(\mathrm{P}-1)\right]\left(\mathrm{T}-\mathrm{T}_{\mathrm{m}}^{\mathrm{P}}\right)+28.163\{[\mathrm{~T} \ln (\mathrm{T})-\mathrm{T}]$

$$
\left.-\left[\mathrm{T}_{\mathrm{m}}^{\mathrm{P}} \ln \left(\mathrm{T}_{\mathrm{m}}^{\mathrm{P}}\right)-\mathrm{T}_{\mathrm{m}}^{\mathrm{P}}\right]\right\}-1.509\left(10^{-4}\right)\left[\mathrm{T}^{2}-\left(\mathrm{T}_{\mathrm{m}}^{\mathrm{P}}\right)^{2}\right]+2.0645\left(10^{6}\right)\left(\frac{1}{\mathrm{~T}}-\frac{1}{\mathrm{~T}_{\mathrm{m}}^{\mathrm{P}}}\right) \text {. }
$$

The dry solidus ${ }^{\mathrm{b}}: \mathrm{T}_{\mathrm{m}}^{\mathrm{P}}(\mathrm{K})=1664+.0126 \mathrm{P}-4.93\left(10^{-8}\right) \mathrm{P}^{2}$

Albite $\left(\mathrm{NaAISi}_{3} \mathrm{O}_{8}\right)$ :

$\Delta \overline{\mathrm{S}}_{\mathrm{f}}(\mathrm{T}, \mathrm{P})^{\mathrm{c}}=\Delta \overline{\mathrm{S}}_{\mathrm{f}}^{\mathrm{o}}\left(\mathrm{T}_{\mathrm{m}}^{\mathrm{o}}, 1\right)+72.27 \ln \left(\mathrm{T}_{\mathrm{m}}^{\mathrm{o}}\right)-3.506\left(10^{-2}\right)\left(\mathrm{T}_{\mathrm{m}}^{\mathrm{o}}\right)-3.793\left(10^{5}\right)\left(\mathrm{T}_{\mathrm{m}}^{\mathrm{o}}\right)^{-2}+3.812\left(10^{3}\right)\left(\mathrm{T}_{\mathrm{m}}^{\mathrm{o}}\right)^{-1 / 2}+4.3725\left(10^{6}\right)\left(\mathrm{T}_{\mathrm{m}}^{\mathrm{o}}\right)^{2}-6.93\left(10^{-6}\right)(\mathrm{P}-1)$ $-72.27 \ln (\mathrm{T})+3.506\left(10^{-2}\right)(\mathrm{T})+3.793\left(10^{5}\right)\left(\mathrm{T}^{-2}\right)-3.812\left(10^{3}\right) \mathrm{T}^{1 / 2}-4.3725\left(10^{-6}\right) \mathrm{T}^{2}$

$\Delta \overline{\mathrm{S}}_{\mathrm{f}}^{\mathrm{o}}\left(\mathrm{T}_{\mathrm{m}}^{\mathrm{o}}, 1\right)=10.90 \mathrm{cal} / \mathrm{K}$ mole where $\mathrm{T}_{\mathrm{m}}^{\mathrm{o}}=1373 \mathrm{~K}$ at $1 \mathrm{bar}$. 


$$
\begin{aligned}
\int_{\mathrm{T}_{\mathrm{m}}^{\mathrm{P}}}^{\mathrm{T}} \Delta \widehat{\mathrm{S}}_{\mathrm{f}}(\mathrm{T}, \mathrm{P}) \mathrm{dT}= & {\left[\Delta \overline{\mathrm{S}}_{\mathrm{f}}^{\mathrm{o}}\left(\mathrm{T}_{\mathrm{m}}^{\mathrm{o}}, 1\right)+72.27 \ln \left(\mathrm{T}_{\mathrm{m}}^{\mathrm{o}}\right)-3.506\left(10^{-2}\right)\left(\mathrm{T}_{\mathrm{m}}^{\mathrm{o}}\right)-3.793\left(10^{5}\right)\left(\mathrm{T}_{\mathrm{m}}^{\mathrm{o}}\right)^{-2}+3.812\left(10^{3}\right)\left(\mathrm{T}_{\mathrm{m}}^{\mathrm{o}}\right)^{-1 / 2}+4.3725\left(10^{-6}\right)\left(\mathrm{T}_{\mathrm{m}}^{\mathrm{o}}\right)^{2}\right.} \\
& \left.-6.93\left(10^{-6}\right)(\mathrm{P}-1)\right]\left(\mathrm{T}-\mathrm{T}_{\mathrm{m}}^{\mathrm{P}}\right)-72.27\left\{[\mathrm{~T} \ln (\mathrm{T})-\mathrm{T}]-\left[\mathrm{T}_{\mathrm{m}}^{\mathrm{P}} \ln \left(\mathrm{T}_{\mathrm{m}}^{\mathrm{P}}\right)-\mathrm{T}_{\mathrm{m}}^{\mathrm{P}}\right]\right\}+1.753\left(10^{-2}\right)\left[\mathrm{T}^{2}-\left(\mathrm{T}_{\mathrm{m}}^{\mathrm{P}}\right)^{2}\right] \\
& -3.793\left(10^{5}\right)\left(\frac{1}{\mathrm{~T}}-\frac{1}{\mathrm{~T}_{\mathrm{m}}^{\mathrm{P}}}\right)-7.624\left(10^{3}\right)\left[\mathrm{T}-\left(\mathrm{T}_{\mathrm{m}}^{\mathrm{P}}\right)^{1 / 2}\right]-1.4575\left(10^{-6}\right)\left[\mathrm{T}^{3}-\left(\mathrm{T}_{\mathrm{m}}^{\mathrm{P}}\right)^{3}\right]
\end{aligned}
$$

The dry solidus ${ }^{\mathrm{d}}: \mathrm{T}_{\mathrm{m}}^{\mathrm{P}}(\mathrm{K})=1373+.0095 \mathrm{P}$

Silica $\left(\beta-\mathrm{SiO}_{2}\right)$ :

$\Delta \overline{\mathrm{S}}_{\mathrm{f}}(\mathrm{T}, \dot{\mathrm{P}})^{\mathrm{e}}=\Delta \mathrm{S}_{\mathrm{f}}^{\mathrm{o}}\left(\mathrm{T}_{\mathrm{m}}^{\mathrm{o}}, 1\right)-1.2089\left(10^{-6}\right)(\mathrm{P}-1)-3.847 \ln \left(\mathrm{T}_{\mathrm{m}}^{\mathrm{o}}\right)+1.321\left(10^{-3}\right)\left(\mathrm{T}_{\mathrm{m}}^{\mathrm{o}}\right)+2.2064\left(10^{5}\right) /\left(\mathrm{T}_{\mathrm{m}}^{\mathrm{o}}\right)^{2}+3.847 \ln (\mathrm{T})-1.321\left(10^{-3}\right) \mathrm{T}$ $-2.2064\left(10^{5}\right) / T^{2}$

$\Delta \overline{\mathrm{S}}_{\mathrm{f}}^{\mathrm{o}}\left(\mathrm{T}_{\mathrm{m}}^{\mathrm{o}}, 1\right)=1.32 \mathrm{cal} / \mathrm{K}$ mole where $\mathrm{T}_{\mathrm{m}}^{\mathrm{o}}=1700 \mathrm{~K}$ at $1 \mathrm{bar}$.

$\int_{T_{m}^{P}}^{\mathrm{T}} \Delta \overline{\mathrm{S}}_{\mathrm{f}}(\mathrm{T}, \mathrm{P}) \mathrm{dT}=\left[\Delta \overline{\mathrm{S}}_{\mathrm{f}}^{\mathrm{o}}\left(\mathrm{T}_{\mathrm{m}}^{\mathrm{o}}, 1\right)-1.2089\left(10^{-6}\right)(\mathrm{P}-1)-3.847 \ln \left(\mathrm{T}_{\mathrm{m}}^{\mathrm{o}}\right)+1.321\left(10^{-3}\right)\left(\mathrm{T}_{\mathrm{m}}^{\mathrm{o}}\right)+2.2064\left(10^{5}\right) /\left(\mathrm{T}_{\mathrm{m}}^{\mathrm{o}}\right)^{2}\right]\left(\mathrm{T}-\mathrm{T}_{\mathrm{m}}^{\mathrm{P}}\right)$

$$
+3.847\left\{[\mathrm{~T} \ln (\mathrm{T})-\mathrm{T}]-\left[\mathrm{T}_{\mathrm{m}}^{\mathrm{P}} \ln \left(\mathrm{T}_{\mathrm{m}}^{\mathrm{P}}\right)-\mathrm{T}_{\mathrm{m}}^{\mathrm{P}}\right]\right\}-6.607\left(10^{-4}\right)\left[\mathrm{T}^{2}-\left(\mathrm{T}_{\mathrm{m}}^{\mathrm{P}}\right)^{2}\right]+2.2064\left(10^{5}\right)\left(\frac{1}{\mathrm{~T}}-\frac{1}{\mathrm{~T}_{\mathrm{m}}^{\mathrm{P}}}\right)
$$

The dry solidusf: $\mathrm{T}_{\mathrm{m}}^{\mathrm{P}}(\mathrm{K})=1700+.0469 \mathrm{P}-5.89 \times 10^{-7} \mathrm{P}^{2}$

Notes._Units in above equations: $T$ in Kelvin, $P$ in bars. $\Delta \bar{V}$ enters into the calculation for $\Delta \bar{S}_{f}$ as follows: $\Delta \bar{S}_{f}(T, P)=\Delta S_{f}\left(T_{m}^{0}, 1\right)+\int_{T_{m}^{0}}^{T} \frac{\Delta \bar{c}_{P}}{T} d T-\int_{1}^{P} \alpha \Delta \bar{V} d P$

$\Delta \overline{\mathrm{H}}_{\mathrm{f}}, \Delta \overline{\mathrm{C}}_{\mathrm{p}}$ : Stebbins et al. (1983), $\alpha$ : Skinner (1966), $\Delta \overline{\mathrm{V}}$ : Ghiorso and Carmichael (1980)

Best-fit curve to Boettcher et al. (1982).

$\Delta \overline{\mathrm{H}}_{\mathrm{f}}, \Delta \overline{\mathrm{C}}_{\mathrm{p}}$ : Stebbins et al. (1983), $\alpha$ : Skinner (1966), $\Delta \overline{\mathrm{V}}$ : Ghiorso and Carmichael (1980)

Best-fit curve to Boettcher et al. (1982).

$\Delta \overline{\mathrm{H}}_{\mathrm{f}}, \Delta \overline{\mathrm{C}}_{\mathrm{p}}$ : Richet et al. (1982), $\alpha$ : Bottinga and Weill (1970). $\Delta \mathrm{V}$ : Ghiorso and Carmichael (1970), Richet et al. (1982).

Best-fit curve to Jackson (1976). 


$$
\begin{gathered}
\ln \mathrm{K}_{2}\left(\mathrm{P}_{\mathrm{r}}, \mathrm{T}_{\mathrm{r}}\right)=\left[\mu_{\mathrm{H}_{2} \mathrm{O}}^{\mathrm{O} \mathrm{V}}\left(\mathrm{P}_{\mathrm{r}}, \mathrm{T}_{\mathrm{r}}\right)\right. \\
\left.-\mu_{\mathrm{H}_{2} \mathrm{O}, \mathrm{mol}}^{\mathrm{o} . \mathrm{m}}\left(\mathrm{P}_{\mathrm{r}}, \mathrm{T}_{\mathrm{r}}\right)\right] / \mathrm{RT}_{\mathrm{r}}=\Delta \mu^{\mathrm{o}}\left(\mathrm{P}_{\mathrm{r}}, \mathrm{T}_{\mathrm{r}}\right) / \mathrm{RT}_{\mathrm{r}}
\end{gathered}
$$

We assume that solubility is independent of temperature at the reference pressure, i.e., $\left(\partial \Delta \mu^{\mathrm{O}} / \partial \mathrm{T}\right)_{\mathrm{P}_{\mathrm{r}}}=\mathrm{O}$. This is valid as a first approximation because the temperature dependence of solubility is small (Burnham and Jahns 1962; Karsten et al. 1981). This assumption does, however, lead to a small variation in solubility with temperature at $P \neq P_{r}$, as explained below. Since $(\partial \mu / \partial \mathrm{P})_{\mathrm{T}}=\overline{\mathrm{V}}$, we obtain:

$$
\begin{aligned}
\Delta \mu^{\mathrm{o}}(\mathrm{P}, \mathrm{T})= & \Delta \mu^{\mathrm{o}}\left(\mathrm{P}_{\mathrm{r}}, \mathrm{T}_{\mathrm{r}}\right)+\int_{\mathrm{P}_{\mathrm{r}}}^{\mathrm{P}} \overline{\mathrm{V}}_{\mathrm{H}_{2} \mathrm{O}}^{\mathrm{V}}(\mathrm{P}, \mathrm{T}) \mathrm{dP} \\
& -\int_{\mathrm{P}_{\mathrm{r}}}^{\mathrm{P}} \overline{\mathrm{V}}_{\mathrm{H}_{2} \mathrm{O}, \mathrm{mol}}^{\mathrm{m}}(\mathrm{P}, \mathrm{T}) \mathrm{dP}
\end{aligned}
$$

where $\overline{\mathrm{V}}_{\mathrm{H}, \mathrm{O}}^{\mathrm{v}}(\mathrm{P}, \mathrm{T})$ and $\overline{\mathrm{V}}_{\mathrm{H}, \mathrm{O}, \mathrm{mol}}^{\mathrm{m}}(\mathrm{P}, \mathrm{T})$ are the partial molar volumes of water in the vapor and of molecular water in the melt.

For water in the vapor,

$$
\int_{\mathrm{P}_{\mathrm{r}}}^{\mathrm{P}} \overline{\mathrm{V}}_{\mathrm{H}_{2} \mathrm{O}}^{\mathrm{v}}(\mathrm{P}, \mathrm{T}) \mathrm{dP}=\mathrm{RT} \ln \left[\mathrm{f}_{\mathrm{H}_{2} \mathrm{O}}^{\mathrm{O}}(\mathrm{P}, \mathrm{T}) / \mathrm{f}_{\mathrm{H}_{2}}^{\mathrm{O}} \mathrm{O}\left(\mathrm{P}_{\mathrm{r}}, \mathrm{T}\right)\right]
$$

We have calculated $\mathrm{f}_{\mathrm{H}_{\mathrm{O}} \mathrm{O}}^{\mathrm{O}}(\mathrm{P}, \mathrm{T})$, the fugacity of pure $\mathrm{H}_{2} \mathrm{O}$ at $\mathrm{T}$ and $\mathrm{P}$, from the modified Redlich-Kwong equation of state for $\mathrm{H}_{2} \mathrm{O}$ (Holloway 1977; Flowers 1979).

To use equation (20), we must estimate the partial molar volume of molecular water in the melt. Instead of using a constant value for $\overline{\mathrm{V}}_{\mathrm{H}_{2} \mathrm{O} \text {,mol }}^{\mathfrak{m}}$ in evaluating equation (20), we have allowed it to decrease with increasing pressure as a result of compression. We have assumed that $\overline{\mathrm{V}}_{\mathrm{H}_{2} \mathrm{O} \text {,mol }}$ is independent of temperature. This approximation is based on the fact that for reasonable values of $\alpha$, the coefficient of thermal expansion, $\overline{\mathrm{V}}_{\mathrm{H}, \mathrm{O}, \mathrm{mol}}^{\mathrm{m}}$ would vary only by a percent or two over the temperature range of interest. We have modeled the pressure dependence using the Murnaghan equation:

$$
\begin{aligned}
& \overline{\mathrm{V}}_{\mathrm{H}_{2} \mathrm{O}, \mathrm{mol}}^{\mathrm{m}}(\mathrm{P})=\overline{\mathrm{V}}_{\mathrm{H}_{2} \mathrm{O}, \mathrm{mol}}^{\mathrm{m}}(1) \\
& {\left[1+\frac{\mathrm{B}^{\prime}}{\mathrm{B}_{\mathrm{o}}}\left(\mathrm{P}-\mathrm{P}_{\mathrm{o}}\right)\right]^{-1 / \mathrm{B}^{\prime}}}
\end{aligned}
$$

In this equation, $B_{o}$ is the isothermal bulk modulus at $1 \mathrm{bar}, \mathrm{B}^{\prime}$ is the pressure derivative of $\mathbf{B}, \overline{\mathrm{V}}_{\mathrm{H}_{2} \text {, mol }}^{\mathrm{m}}(1)$ is the partial molar volume of dissolved molecular water at $1 \mathrm{bar}$. We have chosen $B_{0}=200 \mathrm{kbar}$ and $\mathrm{B}^{\prime}=4$, typical values for oxygens in silicate melts (Stolper et al. 1981). $\overline{\mathrm{V}}_{\mathrm{H}_{2} \mathrm{O} \text {,mol }}^{\mathrm{m}}(\mathrm{P})$ is then given by,

$$
\overline{\mathrm{V}}_{\mathrm{H}_{2} \mathrm{O}, \mathrm{mol}}^{\mathrm{m}}(\mathrm{P})=\overline{\mathrm{V}}_{\mathrm{H}_{2} \mathrm{O}, \mathrm{mol}}^{\mathrm{m}}(1)\left[1+2\left(10^{-5}\right) \mathrm{P}\right]^{-1 / 4}
$$

Then,

$$
\begin{aligned}
& \int_{\mathrm{P}_{\mathrm{r}}}^{\mathrm{P}} \overline{\mathrm{V}}_{\mathrm{H}_{2} \mathrm{O}, \mathrm{mol}}^{\mathrm{m}}(\mathrm{P}) \mathrm{dP}=\frac{2}{3}\left(10^{5}\right) \overline{\mathrm{V}}_{\mathrm{H}_{2} \mathrm{O}, \mathrm{mol}}^{\mathrm{m}}(1) \\
& \left\{\left[1+2\left(10^{-5}\right) \mathrm{P}\right]^{3 / 4}-\left[1+2\left(10^{-5}\right) \mathrm{P}_{\mathrm{r}}\right]^{3 / 4}\right\}
\end{aligned}
$$

Substituting eqs. (20), (21) and (23) into eq. (19) leads to the following expression for the variation of $K_{2}$ with pressure and temperature:

$$
\begin{gathered}
\ln \mathrm{K}_{2}(\mathrm{P}, \mathrm{T})=\ln \left(\mathrm{a}_{\mathrm{H}_{2} \mathrm{O}, \mathrm{mol}}^{\mathrm{m}} / \mathrm{a}_{\mathrm{H}_{2} \mathrm{O}}^{\mathrm{O}}\right) \\
=\ln \mathrm{K}_{2}\left(\mathrm{~T}_{\mathrm{r}}, \mathrm{P}_{\mathrm{r}}\right)+\ln \left[\mathrm{f}_{\mathrm{H}_{2} \mathrm{O}}^{\mathrm{O}}(\mathrm{P}, \mathrm{T}) / \mathrm{f}_{\mathrm{H}_{2} \mathrm{O}}^{\mathrm{o}}\left(\mathrm{P}_{\mathrm{r}}, \mathrm{T}\right)\right] \\
-\frac{2}{3}\left(10^{5}\right) \overline{\mathrm{V}}_{\mathrm{H}_{2} \mathrm{O}, \mathrm{mol}}^{\mathrm{m}}(1)\left\{\left[1+2\left(10^{-5}\right) \mathrm{P}\right]^{3 / 4}\right. \\
\left.-\left[1+2\left(10^{-5}\right) \mathrm{P}_{\mathrm{r}}\right]^{3 / 4}\right\} / \mathrm{RT}
\end{gathered}
$$

What values should we use for $\overline{\mathrm{V}}_{\mathrm{H}_{2} \mathrm{O} \text {,mol }}^{\mathrm{m}}(1)$ in equation (24)? Our assumption of ideal mixing implies that the volumes of the molecular species should be similar to each other. According to Guggenheim (1952) they should differ by less than about $30 \%$ if ideal mixing is to hold. The molar volume of oxygen atoms in albite melt at $1100^{\circ} \mathrm{C}$ is about 14 $\mathrm{cm}^{3}$ (Arndt and Häberle 1973). If anything, we would expect $\overline{\mathrm{V}}_{\mathrm{H}_{2} \mathrm{O} \text {,mol }}$ to be somewhat greater than $\overline{\mathrm{V}}_{\mathrm{O}}^{\mathrm{m}}$. Thus we can expect that if the assumptions of our model are to hold, $\overline{\mathrm{V}}_{\mathrm{H}_{2} \mathrm{O} \text {,mol }}^{\mathrm{m}}\left(1 \mathrm{bar}, 1100^{\circ} \mathrm{C}\right)$ should be between 14 and $18.5 \mathrm{~cm}^{3} /$ mole. At high water contents where most of the water would be present in the melt as molecular water for the $K_{1}$ values that we have determined both spectroscopically (Stolper 1982) and using equation (15), the partial molar volume of water determined experimentally would be similar to $\overline{\mathrm{V}}_{\mathrm{H}_{2} \mathrm{O}, \mathrm{mol}}$. Based on the data of Burnham and Davis (1971), in which the densities of albitic melt 
with 8.25 and 10.9 wt \% dissolved water are reported over a range of pressures and temperatures, $\overline{\mathrm{V}}_{\mathrm{H}_{2} \mathrm{O}}^{\mathrm{m}} \cong \overline{\mathrm{V}}_{\mathrm{H}_{2} \mathrm{O} \text {,mol }}^{\mathrm{m}}$ is in the range of 15-17 cc/mole, similar to that estimated above. Hodges (1974) calculated a similar value of $16.5 \mathrm{cc} / \mathrm{mole}$ for $\overline{\mathrm{V}}_{\mathrm{H}_{2} \mathrm{O}}$ in diopside melt at $20 \mathrm{~kb}$. While all values of $\overline{\mathrm{V}}_{\mathrm{H}_{2} \mathrm{O} \text {,mol }}(1)$ in the range of $15-18 \mathrm{cc} /$ mole result in solution models consistent with available phase equilibrium data, we have chosen values in the range of $16.4-17.8 \mathrm{cc} /$ mole since these result in the best matches between our model phase equilibria and experimental data.

Our approach has been to assume a value for $\overline{\mathrm{V}}_{\mathrm{H}_{2} \mathrm{O} \text {,mol }}^{\mathrm{m}}(1)$ and a variation of this partial molar volume with pressure according to the Murnaghan equation and then to use these values to calculate the wet solidus. This calculated solidus is then compared to the actual solidus based on experiment. Alternatively, we could have solved for the $\overrightarrow{\mathrm{V}}_{\mathrm{H}_{2} \mathrm{O} \text {,mol as a }}^{\mathrm{m}}$ function of pressure that precisely matched the best fit solidus. The volumes determined in this alternate way are essentially similar to those that we have derived from the Murnaghan equation.

Given a choice of a reference point on the wet solidus, which allows us to fix $K_{1}$ and $K_{2}$ at this reference point (equations 15 and 16), equation (24) can be used to calculate $K_{2}$ at any other pressure and temperature. The solubility of water in a silicate melt for any value of $\mathrm{a}_{\mathrm{H}_{2} \mathrm{O}}^{\mathrm{V}}$ at any $\mathrm{T}$ and $\mathrm{P}$ can then be calculated by substitution of $K_{2}(P, T)$ from equation (24) and $a_{H_{2} \mathrm{O}}^{\mathrm{V}}$ into equation (10) to give $\mathrm{X}_{\mathrm{B}}$. The temperature of the wet solidus can then be calculated by equating equation (10) and solving for $\mathrm{T}$. In practice, we did not determine an analytic expression for $T$ but instead for each $P$ calculated $X_{B}$ as a function of $T$ for the undersaturated liquidus and $\mathrm{X}_{\mathrm{B}}$ for $\mathrm{a}_{\mathrm{H}_{2} \mathrm{O}}^{\mathrm{V}}=1$ as a function of $T$ from equations (24) and (10) and took their intersection as the wet solidus.

\section{RESULTS}

As discussed above, the goal of this paper is to see whether the thermodynamic formulation for hydrous silicate melts that we have developed based on our molecular model is consistent with available phase equilibrium data. In the paragraphs that follow, we discuss the application of this model to the systems albite- $\mathrm{H}_{2} \mathrm{O}$, diopside- $\mathrm{H}_{2} \mathrm{O}$, and silica$\mathrm{H}_{2} \mathrm{O}$.
1. Albite $-\mathrm{H}_{2} \mathrm{O}$. - The reference point is $\mathrm{P}_{\mathrm{r}}$ $=5000$ bars, $\mathrm{T}_{\mathrm{r}}=745^{\circ} \mathrm{C}$, with a total water solubility at $\mathrm{T}_{\mathrm{r}}, \mathrm{P}_{\mathrm{r}}$ of $9 \mathrm{wt} \% \mathrm{H}_{2} \mathrm{O} . \Delta \overline{\mathrm{S}}_{\mathrm{f}}(\mathrm{P}, \mathrm{T})$ is based on Stebbins et al. (1983) and is given in table 1. We have chosen $\overline{\mathrm{V}}_{\mathrm{H}_{2} \mathrm{O} \text {,mol }}^{\mathrm{m}}$ (1) to be 16.4 $\mathrm{cc} / \mathrm{mole}$. The dry solidus is from Boettcher et al. (1982). The calculated value of $K_{1}$ is 0.17 . This is similar to $\mathbf{K}_{1}$ values determined by infrared spectroscopic measurements on hydrous albite and rhyolitic glasses (Stolper, $1982 a, 1982 b$ ).

Calculated isobaric sections for albite $-\mathrm{H}_{2} \mathrm{O}$ are shown in figure 1 for $\mathrm{P}=2000,5000$ and 10,000 bars. In principle, the positions of these liquidus boundaries could be determined experimentally and used to test our calculated liquidus boundaries; however, there are few available data points of this type.

The results of the calculation of the wet solidus for albite- $\mathrm{H}_{2} \mathrm{O}$ are shown in figure 2 . Shown for comparison are experimental determinations of the wet solidus reported in the literature. The agreement between our calculated solidus and the experimental data is excellent over the entire pressure range.

Figure 3 shows the variation in solubility of $\mathrm{H}_{2} \mathrm{O}$ in albite melt as a function of $\mathrm{P}$ calculated using our model. Shown for comparison is a collection of experimental solubility determinations from the literature. The calculated solubility curve falls within the range of the experimental data for $\mathrm{P}$ up to $8 \mathrm{kbar}$; at higher $\mathbf{P}$, our model solubility and the experimental determinations diverge.

2. Diopside $-\mathrm{H}_{2} \mathrm{O}$. - The reference point was chosen as $\mathrm{P}_{\mathrm{r}}=6000$ bars, $\mathrm{T}_{\mathrm{r}}=1265^{\circ} \mathrm{C}$, with a total water solubility at $T_{r}, P_{r}$ of $8.0 \mathrm{wt}$ $\% \mathrm{H}_{2} \mathrm{O}$ (Eggler and Burnham, 1984). The $\Delta \overline{\mathrm{S}}_{\mathrm{f}}(\mathrm{P}, \mathrm{T})$ is based on Stebbins et al. (1983) and is given in table $1 . \overline{\mathrm{V}}_{\mathrm{H}_{2} \mathrm{O} \text {,mol }}^{\mathrm{m}}(1)$ was taken to be $17.8 \mathrm{cc} /$ mole. The dry solidus is from Boettcher et al. (1982). The calculated $\mathrm{K}_{1}$ value is 0.085 . This lower value for diopside than for albite may indicate that more water dissolves as molecular water in diopside than in albite melt for a given total water content. As mentioned earlier, choosing other points along the solidus and solubility curves as references does result in different values for $\mathrm{K}_{1}$ (e.g., for diopside, a $30 \mathrm{kbar}$ point yields $\mathrm{K}_{1}$ $=0.07$, a $20 \mathrm{kbar}$ point yields $\mathrm{K}_{1}=0.04$ and a 2 kbar point gives $K_{1}=0.02$ ), but these differences do not critically affect the results of the calculation. 


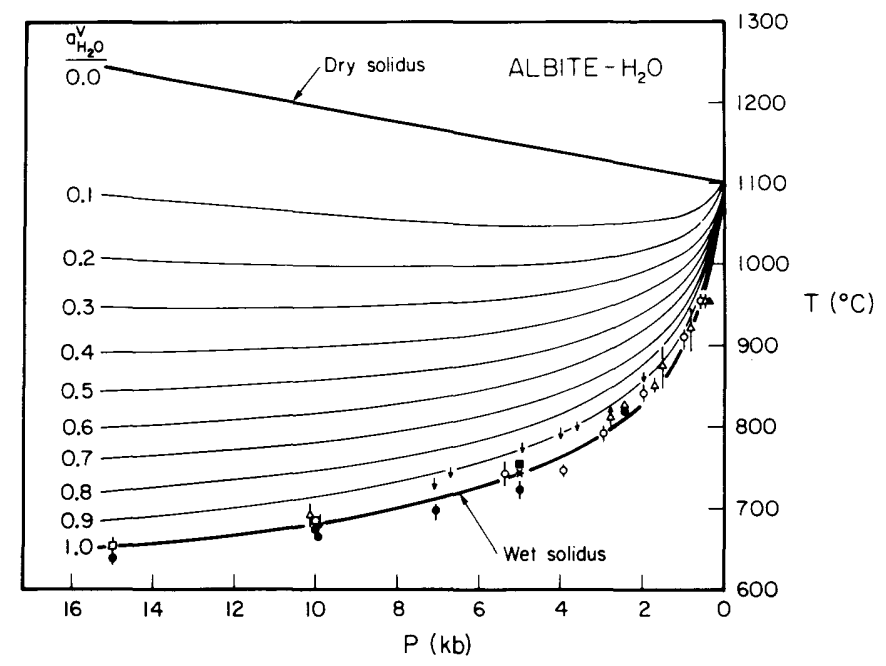

Fig. 2.-The wet solidus for albite up to $15 \mathrm{~kb}$. Symbols with brackets represent experimental data with estimated uncertainties from: white triangles-Goranson (1938); white circles-Tuttle and Bowen (1959); black triangles - Luth et al. (1964) corrected by Luth (1976); white squares-Boettcher and Wyllie (1969); black squares-Morse (1970); and black circles-Bohlen et al. (1982). Arrows represent upper temperature limits from Burnham and Jahns (1962). The heavy solid line represents our calculated wet solidus for $\overline{\mathrm{V}}_{\mathrm{H}_{2} \mathrm{O} \text {.noll }}^{\mathrm{m}}(1)=16.4 \mathrm{cc} / \mathrm{mole}, \mathrm{K}_{1}=0.174$. The lighter lines represent contours for $\mathrm{a}_{\mathrm{H}_{2} \mathrm{O}}$ from 0.1 to 0.9 . The dry solidus is a best-fit curve based on data from Boettcher et al. (1982). The reference point is an average value based on data from Burnham and Jahns (1962), Morse (1970) and Bohlen et al. (1982) and is shown by an asterisk. See text for details.

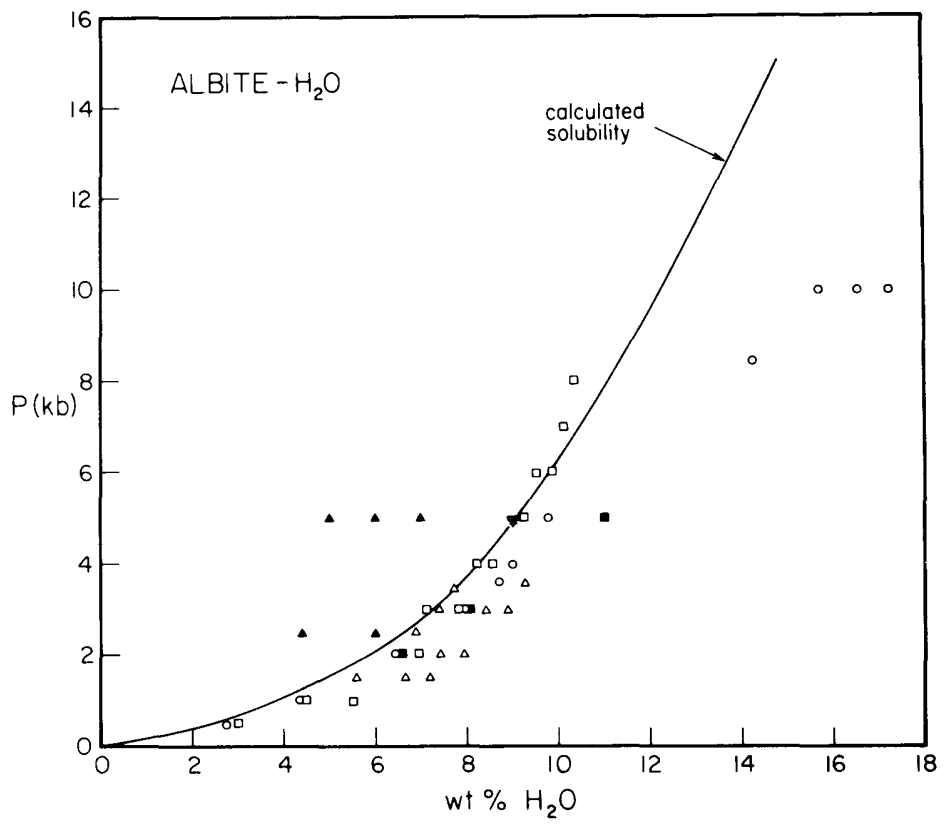

Fig. 3.- The solubility of $\mathrm{H}_{2} \mathrm{O}$ in albite melt as a function of $\mathrm{P}$ at temperatures near the wet solidus. Symbols represent experimental data from: white triangles-Goranson (1938); white circles-Burnham and Jahns (1962); black squares-Khitarov et al. (1963); white squares-Oxtoby and Hamilton (1978); white triangles-Voigt et al. (1981) and black triangles-Day and Fenn (1982). Most of the data were derived from compilations by Bottinga et al. (1981) and Day and Fenn (1982). The solid curve represents solubility calculated with our model. The reference point was taken from Voigt et al. (1981) and is shown by an asterisk. 
The results of our model calculations for the wet solidus for diopside are shown in figure 4 along with available experimental data. Again, the agreement between our calculated solidus and the experimental data up to $30 \mathrm{kbar}$ is excellent.

Figure 5 compares the calculated solubility of $\mathrm{H}_{2} \mathrm{O}$ in diopside melt as a function of $\mathrm{P}$ with values from the literature. Our model is consistent with the experimental data up to 20 kbar. Owing to a large discrepancy in the solubility determinations at $30 \mathrm{kbar}$, it is difficult to judge our model curve against actual data. However, our calculated values compare well with Hodges' (1974) determination of $21.5 \mathrm{wt} \% \mathrm{H}_{2} \mathrm{O}$ at $30 \mathrm{kbar}$.

3. Silica- $\mathrm{H}_{2} \mathrm{O}$.- The reference point was chosen as $\mathrm{P}_{\mathrm{r}}=6000$ bars, $\mathrm{T}_{\mathrm{r}}=1070^{\circ} \mathrm{C}$ and water solubility at $\mathrm{P}_{\mathrm{r}}, \mathrm{T}_{\mathrm{r}}$ of $6.0 \mathrm{wt} \% \mathrm{H}_{2} \mathrm{O}$ (Kennedy et al., 1962). The $\Delta \overline{\mathrm{S}}_{\mathrm{f}}(\mathrm{P}, \mathrm{T})$ is based on Richet et al. (1982) and is given in table 1. $\overline{\mathrm{V}}_{\mathrm{H}_{2} \text { O,mol }}^{\mathrm{m}}(1)$ was taken as $17 \mathrm{cc} /$ mole. The dry solidus was taken from Jackson (1976). The model calculation yields a $K_{1}$ value of 0.11 .

The results of our model calculation of the stable and metastable regions of the wet solidus for $\beta$-quartz are compared with experimental determinations in figure 6 . There is good agreement between the model calculation and the experimental data.

Calculated and measured water solubility as function of $P$ are presented in figure 7 . The agreement between the model and experimental data is good up to $\sim 7$ kbar. For $\mathrm{P}>7$ kbar, the calculated solubility diverges from measured values. This reflects the fact that there is a critical end point at 9-10 kbar (Kennedy et al. 1962; Boettcher 1984). Our model, with its ideal mixing law, cannot account for critical phenomena and thus would not be expected to work well as the critical end point is approached.

\section{DISCUSSION}

The success of the activity-composition relationships for hydrous silicate melts that we have adopted is manifest in figures $2-7$. The shape of the wet solidus and the solubility of water are well accounted for by our model in the systems albite-water, diopside-water, and silica-water over most of the pressure range for which experimental constraints are available. We may thus conclude that the ideal mixing law and the molecular level interactions that we assumed in formulating our

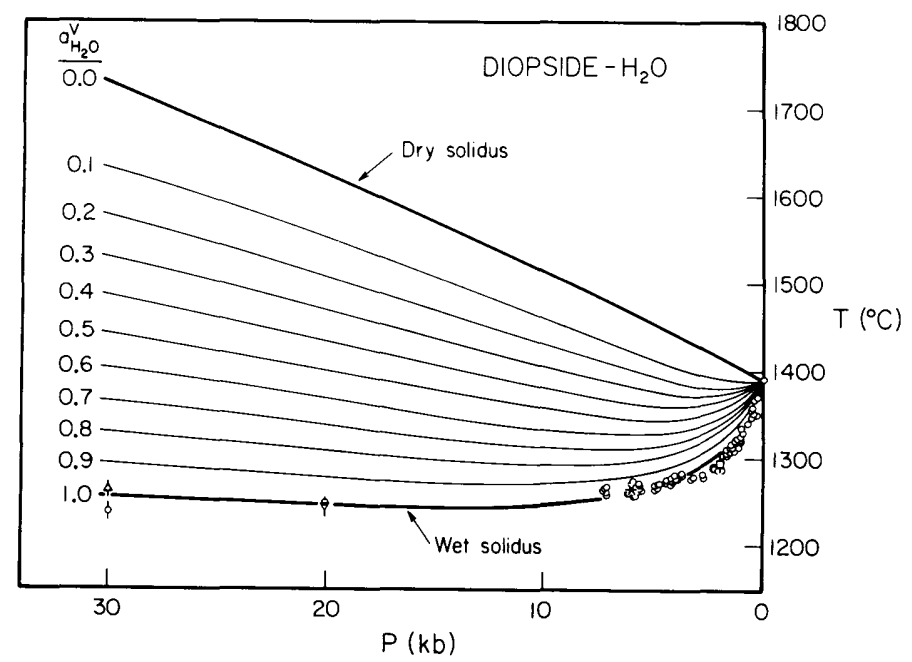

Fig. 4.-The wet solidus for diopside up to $30 \mathrm{~kb}$. Symbols and brackets represent experimental data and estimated uncertainties from: up-pointed triangles_-Eggler (1973); down-pointed triangles-Hodges (1974); white circles-Eggler and Rosenhauer (1978); and white squares-Eggler and Burnham (1984). The heavy solid curve represents our model calculation, with $\overline{\mathrm{V}}_{\mathrm{H}_{2} \mathrm{O} \text {,mol }}(1)=17.8 \mathrm{cc} / \mathrm{mole}, \mathrm{K}_{1}=.085$. The lighter lines are contours of $\mathrm{a}_{\mathrm{H}_{2} \mathrm{O}}^{\mathrm{O}}$ from 0.1 to 0.9 . The dry solidus is a best-fit curve based on data from Boettcher et al. (1982). The reference point was taken from Eggler and Burnham (1984) and is shown by an asterisk. See text for details. 


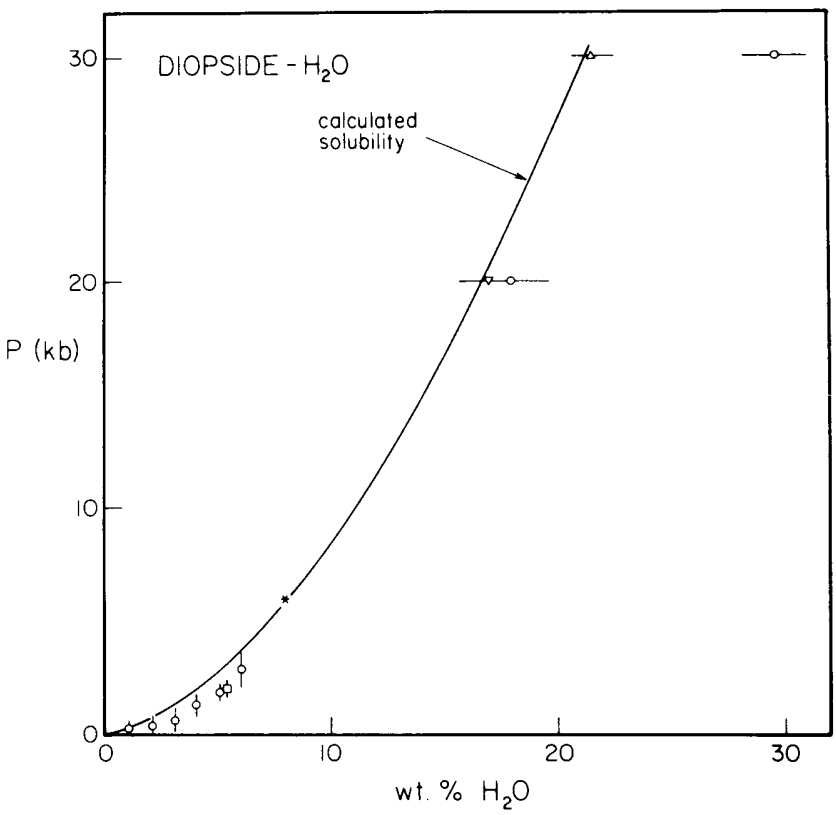

FIG. 5.-The solubility of $\mathrm{H}_{2} \mathrm{O}$ in diopside melt as a function of $\mathrm{P}$ along the solidus. Symbols with brackets represent experimental data from same sources as in figure 4. Solid curve represents $\mathrm{H}_{2} \mathrm{O}$ solubility calculated with our model. The reference point was taken from Eggler and Burnham (1984) and is shown by an asterisk.

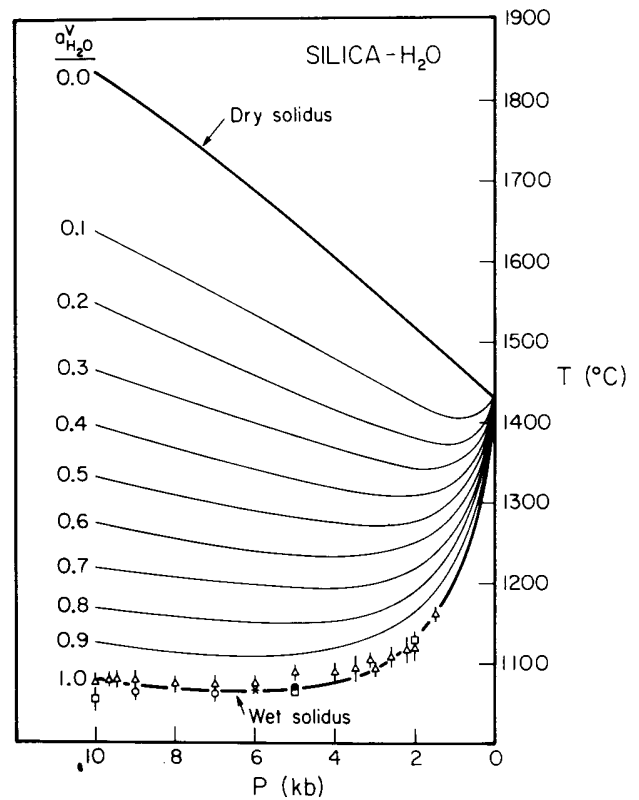

FIG. 6. -The wet solidus for $\beta$-qtz. Symbols with brackets represent experimental data with estimated uncertainties from: black circles-Ostrovskii et al. (1959); white triangles-Kennedy et al. (1962); white squares-Stewart (1967); and white circles-Boettcher (1984). The critical end point is at $\simeq 10 \mathrm{~kb}$. The heavy solid curve is our activity-composition relations are at least permissible descriptions of the solubility mechanisms of water in melts and the species level interactions of hydrous silicate melts. In other words, the concept that molecular water and hydroxyl groups are dissolved in silicate melts and that their relative proportions are controlled through homogeneous equilibria such as that described by equation (1) are consistent with phase equilibrium data.

If all that were available to constrain our thinking on solubility mechanisms and speciation in hydrous silicate melts were experimental data of the sort we have fit in figures $2-7$, we could go no further than the permissive statement made above. Undoubtedly, other formulations of molecular level interactions involving different species and solubility mechanisms could also yield activity-

calculated wet solidus, with $\overline{\mathrm{V}}_{\mathrm{H}_{2} \mathrm{O} \text {.mol }}^{\mathrm{m}}(1)=17 \mathrm{cc} /$ mole, $\mathrm{K}_{1}=0.11$. The lighter curves are contours of $\mathrm{a}_{\mathrm{H}_{2} \mathrm{O}}^{\mathrm{O}}=0.1$ to 0.9 . The dry solidus is a best-fit curve from Jackson (1976) for $P>6 \mathrm{~kb}$ and the 1 bar metastable melting temperature from Richet et al. (1982). The reference point was based on data from Kennedy et al. (1962) and is shown by an asterisk. 


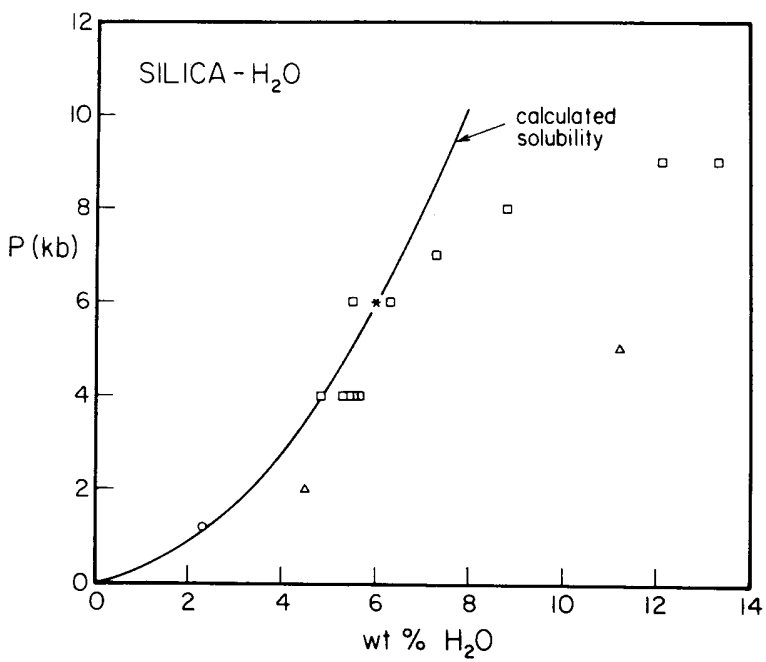

FIG. 7. - The solubility of $\mathrm{H}_{2} \mathrm{O}$ in $\beta$-quartz melt as a function of $\mathrm{P}$ and $\mathrm{T}$ at and above the solidus. Symbols represent experimental data from: circles-Tuttle and England (1955); squares-Kennedy et al. (1962); and triangles-Stewart (1967). The solid curve is our model $\mathrm{H}_{2} \mathrm{O}$ solubility. The reference point is from Stewart (1967) and is shown by an asterisk.

composition relations capable of accounting for the phase equilibrium data. We feel, however, that a much stronger statement about the significance of our results can be made, because our modelling predicts concentrations of molecular water and hydroxyl groups in silicate melts that are similar to the concentrations measured in hydrous silicate glasses using infrared spectroscopy (Stolper 1982a). Spectroscopically determined values of $\mathrm{K}_{1}$ for albitic and rhyolitic glasses of 0.1-0.3 (Stolper 1982a) compare favorably to the values of $0.1-0.2$ determined independently in this paper. Finally, the values of $K_{1}$ consistent with our modelling and the spectroscopic measurements are precisely those that best account for the proportionality between $f_{\mathrm{H}_{2} \mathrm{O}}$ and the square of the mole fraction of the dissolved water at low water contents (Stolper 1982a). Thus, not only does our thermodynamic formulation provide a basis for modelling the macroscopic properties of hydrous silicate melts (e.g., phase equilibria), it also embodies a description of the molecular level structures and interactions of $\mathrm{H}$-bearing species in silicate melts that is, to first order, acceptable.

Further development of this type of model of hydrous silicate melts will, we believe, depend on systematic measurements of the concentrations of molecular water and hydroxyl groups in glasses quenched from melts. The pressure and temperature dependences of $\mathrm{K}_{1}$ that have been neglected in our treatment could then be determined and incorporated into more refined treatments. Stolper et al. (1983) have detected a variation in $K_{1}$ with temperature in hydrous rhyolitic glasses. Nogami and Tomozawa (1984) interpret some of their results on hydrous silica glass in terms of a pressure dependence of $\mathrm{K}_{1}$ (i.e., $\Delta V^{o}$ for reaction (1) was suggested to be negative).

A second refinement would consider that most melts contain several different kinds of "free" oxygens that are undoubtedly energetically distinguishable. Thus, for example, in nearly fully polymerized aluminosilicate melts (e.g., albite) there are bridging oxygens between two $\mathrm{Si}$ tetrahedra, two $\mathrm{Al}$ tetrahedra, and between one $\mathrm{Al}$ and one Si tetrahedron. Recent Raman spectroscopic studies of hydrous glasses in such systems (Mysen et al. 1980; Mysen and Virgo 1980; McMillan et al. 1983) suggest that these oxygens are not equally reactive with water molecules. Our model could easily be extended to include several different types of oxygens each obeying an equilibrium such as that given in equation (1), but with different $\mathrm{K}_{1}$ values. We have not done this because it would introduce two additional constants and 
we do not believe that available experimental data are adequate to constrain them. Likewise for diopsidic melts where bridging, nonbridging and free oxygens (in the sense of Toop and Samis 1962) should probably be distinguished in our treatment, but again data necessary to constrain their individual $\mathrm{K}_{1}$ values are not available.

Our treatment implies a slight dependence of solubility on temperature at most pressures. This effect is illustrated in figures 1 and 8. At $P=P_{r}$, the vapor-saturation boundary is assumed to be vertical, i.e., water solubility is assumed to be independent of temperature at the reference pressure. At $\mathrm{P}=2000$ and 10,000 bars in figure 1 , there are slight slopes to the vapor-saturation boundary (e.g., curve B-C at 2000 bars). This small dependence of solubility on temperature is the result of our assumptions that $\overline{\mathrm{V}}_{\mathrm{H}_{2} \mathrm{O} \text {,mol }}^{\mathrm{m}}$ and $\mathrm{K}_{1}$ are independent of temperature and that $\left(\partial \Delta \mu_{\mathrm{H}_{2} \mathrm{O}}^{\mathrm{O}} / \partial \mathrm{T}\right)_{\mathrm{P}_{\mathrm{r}}}=\mathrm{O}$. There, however, several sets of experimental data on the temperature dependence of solubility available for com-

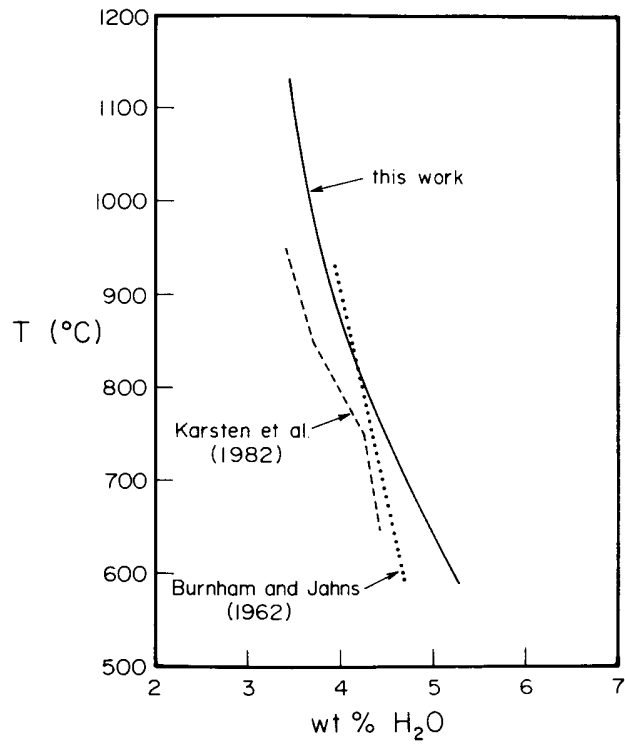

FIG. 8.-The variation of water solubility in silicate melts with temperature. The solid curve represents our calculated solubility for albite at $\mathrm{P}=$ 1000 bars; below $\mathrm{T}=906^{\circ} \mathrm{C}$, this curve is metastable. The dotted curve represents data from Burnham and Jahns (1962) for $\mathrm{H}_{2} \mathrm{O}$ solubility in the Harding pegmatite at $\mathrm{P}=1000$ bars. The dashed curve represents data from Karsten et al. (1982) for the measured $\mathrm{H}_{2} \mathrm{O}$ solubility in rhyolite at $\mathrm{P}=700$ bars. parison with the temperature dependence of solubility implied by our model. Karsten et al. (1982) determined the temperature dependence of water solubility in rhyolitic melt at 700 bars between $650^{\circ} \mathrm{C}$ and $950^{\circ} \mathrm{C}$. Burnham and Jahns (1962) determined solubility for the Harding pegmatite at 1000 bars. These two data sets are shown in figure 8 , along with our calculated solubility for albitic melt at 1000 bars. Although not negligible, the effect of temperature on solubility is small, and more importantly, the magnitude of the temperature dependence that is implicit in our approach is, fortuitously, comparable to available experimental data.

Our approach to the thermodynamics of silicate melts provides an indirect way to determine the partial molar volume of molecular water in silicate melts. Figure 9 shows the calculated solubility of molecular water as $\ln \left(\mathrm{K}_{2}\right)$ at $1000^{\circ} \mathrm{C}$ in diopside, albite and silica as functions of pressure. Because $K_{2}$ is a function of the partial molar volume of water, it is possible to extract the values that we used for the volume of molecular water in the melt from figure 9. Rearrangement and differentiation of equation (24) yields the following:

$$
\left\{\frac{\partial\left[\ln \left(\mathrm{K}_{2} / \mathrm{f}_{\mathrm{H}_{2} \mathrm{O}}^{\mathrm{O}}(\mathrm{P}, \mathrm{T})\right)\right]}{\partial \mathrm{P}}\right\}_{\mathrm{T}}=\frac{-\overline{\mathrm{V}}_{\mathrm{H}_{2} \mathrm{O}, \mathrm{mol}}^{\mathrm{P}}(\mathrm{P}, \mathrm{T})}{\mathrm{RT}}
$$

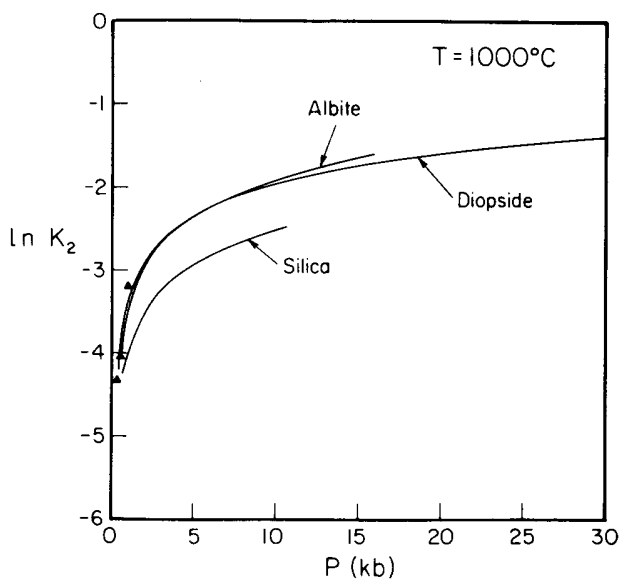

FIG. 9. $-\mathrm{H}_{2} \mathrm{O}$ solubility plotted as $\ln \left(\mathrm{K}_{2}\right)=\ln$ $\left(\mathrm{X}_{\mathrm{H}_{2} \mathrm{O}, \mathrm{mol}}^{\mathrm{m}}\right)$ as a function of $\mathrm{P}$ for hydrous diopside, albite and silica melts. All three curves are at $\mathrm{T}=$ $1000^{\circ} \mathrm{C}$. Black triangles represent measured

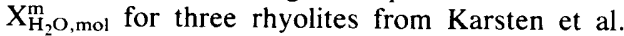
(1982) and Stolper $(1982 b)$. The rhyolites were equilibrated with vapor at $\mathrm{T}=950^{\circ} \mathrm{C}$. 
Thus, when $\ln \left[\mathrm{K}_{2}(\mathrm{P}, \mathrm{T}) / \mathrm{f}_{\mathrm{H}_{2} \mathrm{O}}^{\mathrm{o}}(\mathrm{P}, \mathrm{T})\right]$ is plotted versus $P$, as we have done in figure 10 , the slope of the curve for each composition can be used to compute the partial molar volume of molecular water in the melt. The slopes of the albite, diopside and silica curves in figure 10 simply reflect the values of $\overline{\mathrm{V}}_{\mathrm{H}_{2} \mathrm{O} \text {, mol }}^{\mathrm{m}}$ chosen for our modelling as described previously. However, by using infrared spectroscopy to determine $\mathrm{X}_{\mathrm{H}_{2} \mathrm{O} \text {,mol }}^{\mathrm{m}}\left(=\mathrm{K}_{2}\right)$ in glasses quenched from vapor-saturated melts from different pressures, one could independently determine both $\mathrm{K}_{2}$ and through its pressure dependence, $\overline{\mathrm{V}}_{\mathrm{H}_{2} \mathrm{O} \text {,mol. }}^{\mathrm{m}}$.

Stolper $(1982 a, 1982 b)$ suggested that $\mathrm{K}_{2}$ would probably not be strongly dependent on melt composition. Figures 9 and 10 show that this is indeed the case. The values for albite, diopside and rhyolite (from obsidian samples from Karsten et al. 1982, with $\mathrm{K}_{2}$ values measured spectroscopically by Stolper 1982b), are essentially identical while that for silica is only slightly different. We thus propose that the $K_{2}$ values shown in figures 9 and 10 can be used, along with $K_{1}$ values of $0.1-0.2$, and the equations given in this paper, to calculate phase equilibria and water solubility as func- tions of pressure and temperature for a wide range of melt compositions with a reliability at least comparable to that achieved with empirical treatments (e.g., Burnham 1975, 1979; Eggler and Burnham 1984).

What are the relative merits of our approach to the thermodynamics of hydrous silicate melts versus the largely macroscopic and empirical approaches of Burnham and Davis (1974), Burnham (1979), and Eggler and Burnham (1984) or the regular solution approximations employed by Spera (1974) or Nicholls (1980)? Our feeling is that unless one is interested in modelling systems in the vicinity of critical phenomena, in which case only the approach of Spera (1974) of those that have yet been employed would be applicable, empirical fits of essentially arbitrary activity-composition relationships are less useful than the formulation we have adopted. Granted, these formulations are capable, given sufficient variable parameters, of retrieving the data used to constrain them. However, they have no basis for use in extrapolation, nor do they give any direct insights into melt structures or speciation, nor do they appear to do any better in matching

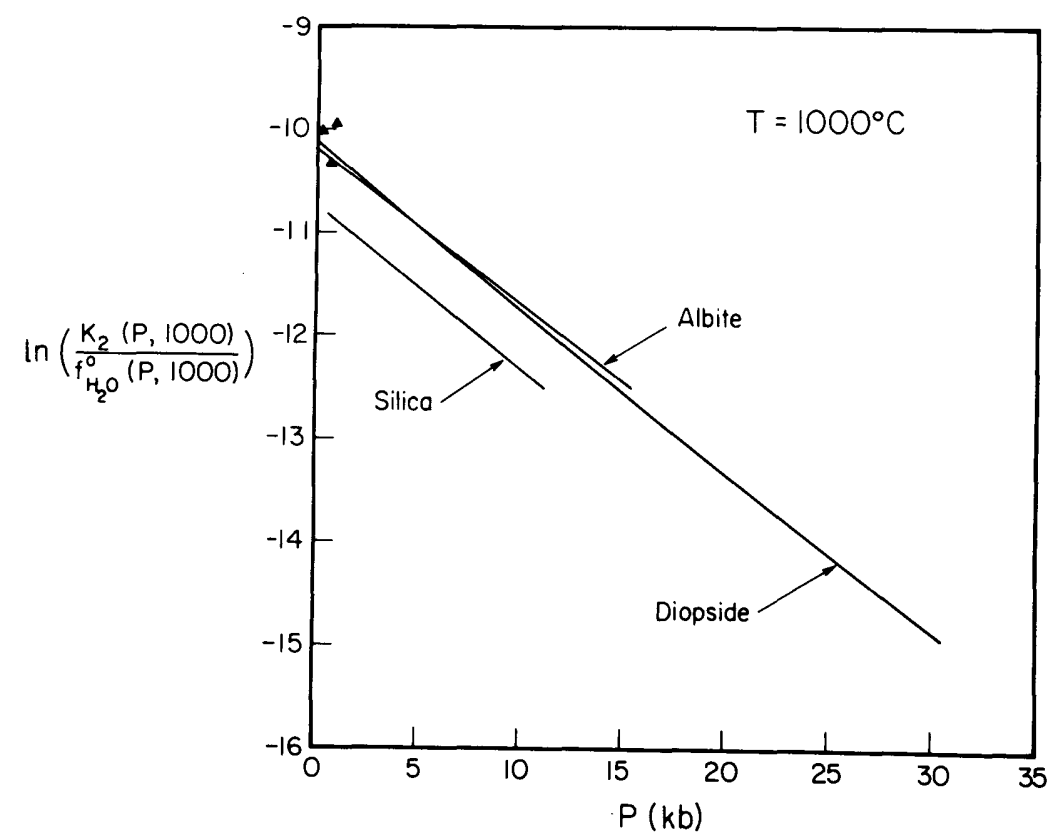

FIG. 10. $-\mathrm{H}_{2} \mathrm{O}$ solubility as $\ln \left[\mathrm{K}_{2} / \mathrm{f}_{\mathrm{H}_{2} \mathrm{O}}^{\circ}(\mathrm{P}, \mathrm{T})\right]$ as a function of $\mathrm{P}$. All three curves are referenced to $\mathrm{T}=$ $1000^{\circ} \mathrm{C}$. The slope of each curve at any point is: $-\left[\overline{\mathrm{V}}_{\mathrm{H}_{2} \mathrm{O}, \mathrm{mol}}^{\mathrm{m}}(\mathrm{P}, \mathrm{T})\right] / \mathrm{RT}$. The closed triangles represent the measured $\mathrm{X}_{\mathrm{H}_{2} \mathrm{O} \text {, mol }}^{\mathrm{m}}$ for three rhyolites (OBS E, OBS G, and OBS I), equilibrated with vapor at $950^{\circ} \mathrm{C}$, from Karsten et al. (1982) and Stolper (1982b). 
phase equilibrium data than do our formulations. In short, the success of our model and its consistency with independent measures of species concentrations makes it more fundamental and more testable, and thus, in the long run, we hope more useful.

\section{CONCLUSIONS}

Thermodynamic modelling of hydrous silicate melts can be approached either by macroscopic, empirical treatments or by modelling species interactions at a molecular level. We have chosen the second approach and have demonstrated that despite its simplicity, our model is successful in accounting for the phase equilibria (i.e., solubility, freezing point depression) of the albite-water, diopside-water and silica-water systems. It has the additional important feature that it is independently testable by and consistent with the available body of spectroscopic measurements of species concentrations of hydrous silicate glasses and melts. It is thus possible to use statistical thermodynamics to produce a viable working model for the macroscopic thermodynamic properties of silicate- $\mathrm{H}_{2} \mathrm{O}$ systems and in the process get testable insights into molecular level phenomena.

AcKnowledgments. - We have benefited from discussions with A. L. Boettcher, T. S. Bowers, and I. S. E. Carmichael and from reviews by M. S. Ghiorso and A. Navrotsky. Supported by NSF Grant EAR-8212765. Division of Geological and Planetary Sciences Contribution \#4124.

\section{REFERENCES CITED}

ARndt, J., and Häberle, F., 1973, Thermal expansion and glass transition temperatures of synthetic glasses of plagioclase-like compositions: Contrib. Mineral. Petrol., v. 39, p. 175-183.

Boettcher, A. L., 1984, The system $\mathrm{SiO}_{2}-\mathrm{H}_{2} \mathrm{O}-$ $\mathrm{CO}_{2}$ : melting, solubility mechanisms of carbon, and liquid structure to high pressures: Am. Mineral., v. 69 , p. $823-833$.

-; Burnham, C. W.; Windom, K. E.; and Bohlen, S. R., 1982, Liquids, glasses, and the melting of silicates to high pressures: Jour. Geology, v. 90, p. 127-138.

, and WYLLIE, P. J., 1969, Phase relationships in the system $\mathrm{NaAlSiO}_{4}-\mathrm{SiO}_{2}-\mathrm{H}_{2} \mathrm{O}$ to 35 kilobars pressure: Am. Jour. Sci., v. 267, p. 875909.

Bohlen, S. R.; Boettcher, A. L.; and Wall, V. J., 1982, The system albite- $\mathrm{H}_{2} \mathrm{O}-\mathrm{CO}_{2}$ : a model for melting and activities of water at high pressures: Am. Mineral., v. 67, p. 451-462.

Bottinga, Y., and Weill, D. F., 1970, Densities of liquid silicate systems calculated from partial molar volumes of oxide components: Am. Jour. Sci., v. 269, p. 169-182.

— - ; and RicheT, P., 1981, Thermodynamic modelling of silicate melts, in Newton, R. D.; NAvrotsky, A.; and Wood, B. J., eds., Thermodynamics of Minerals and Melts: New York, Springer-Verlag, p. 207-245.

Burnham, C. W., 1975, Water and magmas: a mixing model: Geochim. Cosmochim. Acta, v. 39, p. 1077-1084.

1979, The importance of volatile constituents, in Yoder, H. S., JR., ed., The Evolution of the Igneous Rocks: Princeton, Princeton Univ. Press, p. 439-482.

$\longrightarrow$, and Davis, N. F., 1971, The role of $\mathrm{H}_{2} \mathrm{O}$ in silicate melts: I. P-V-T relations in the system $\mathrm{NaAlSi}_{3} \mathrm{O}_{8}-\mathrm{H}_{2} \mathrm{O}$ to 10 kilobars and $1000^{\circ} \mathrm{C}$ : Am. Jour. Sci., v. 270, p. 54-79.
- , and -1974 , The role of $\mathrm{H}_{2} \mathrm{O}$ in silicate melts: II. thermodynamic and phase relations in the system $\mathrm{NaAlSi}_{3} \mathrm{O}_{8}-\mathrm{H}_{2} \mathrm{O}$ to 10 kilobars, $700^{\circ}$ to $1100^{\circ} \mathrm{C}$ : Am. Jour. Sci., v. 274, p. 902-940.

—, and JAHNS, R. H., 1962, A method for determining the solubility of water in silicate melts: Am. Jour. Sci., v. 260, p. 721-745.

DAY, H. W., and FENN, P. M., 1982, Estimating the P-T- $\mathrm{X}_{\mathrm{H}_{2} \mathrm{O}}$ conditions during crystallization of low-calcium granites: Jour. Geology, v. 90, p. 485-507.

EGgler, D. H., 1973, Role of $\mathrm{CO}_{2}$ in melting processes in the mantle: Carnegie Inst. Washington Yearbook, v. 72, p. 457-467.

- and Burnham, C. W., 1984, Solution of $\mathrm{H}_{2} \mathrm{O}$ in diopside melts: a thermodynamic model: Contrib. Mineral. Petrol., v. 85, p. 58-66.

- , and Rosenhauer, M., 1978, Carbon dioxide in silicate melts: II. solubilities of $\mathrm{CO}_{2}$ and $\mathrm{H}_{2} \mathrm{O}$ in $\mathrm{CaMgSi}_{2} \mathrm{O}_{6}$ (diopside) liquids and vapors at pressures to $40 \mathrm{~kb}$ : Am. Jour. Sci., v. 287, p. 64-91.

Flowers, G. C., 1979, Correction of Holloway's (1977) adaptation of the modified Redlich-Kwong equation of state for calculation of the fugacities of molecular species in supercritical fluids of geologic interest: Contrib. Mineral. Petrol., v. 69, p. 315-318.

Ghiorso, M. S., and Carmichael, I. S. E., 1980, A regular solution model for met-aluminous silicate liquids: applications to geothermometry, immiscibility, and the source regions of basic magmas: Contrib. Mineral. Petrol., v. 71, p. 323342 .

Goranson, R. W., 1938, Silicate water systems: phase equilibria in the $\mathrm{NaAISi}_{3} \mathrm{O}_{8}-\mathrm{H}_{2} \mathrm{O}$ and $\mathrm{KAISi}_{3} \mathrm{O}_{8}-\mathrm{H}_{2} \mathrm{O}$ systems at high temperatures and pressures: Am. Jour. Sci., v. 35A, p. 7191. 
Guggenheim, E. A., 1952, Mixtures: Oxford, Oxford University Press, $270 \mathrm{p}$.

Hodges, F. W., 1974, The solubility of $\mathrm{H}_{2} \mathrm{O}$ in silicate melts: Carnegie Inst. Washington Yearbook, v. 73, p. 251-255.

Holloway, J. R., 1977, Fugacity and activity of molecular species in supercritical fluids, in Fraser, D., ed., Thermodynamics in Geology: Boston, D. Reidel, p. 161-181.

JACKSON, I., 1976, Melting of the silica isotypes $\mathrm{SiO}_{2}, \mathrm{BeF}_{2}$, and $\mathrm{GeO}_{2}$ at elevated temperatures: Physics Earth Planet. Interiors, v. 13, p. 218231.

Karsten, J. L.; Holloway, J. R.; and Delaney, J. R., 1982, Ion microprobe studies of water in silicate melts: temperature-dependent water diffusion in obsidian: Earth Planet. Sci. Letters, v. 59 , p. 420-428.

Kennedy, G. C.; Wasserburg, G. J.; Heard, H. L.; and Newton, R. C., 1962, The upper three-phase region in the system $\mathrm{SiO}_{2}-\mathrm{H}_{2} \mathrm{O}: \mathrm{Am}$. Jour. Sci., v. 260, p. 501-521.

Khitarov, N. I.; Kadik, A. S.; and LebedeV, E. B., 1963, Estimate of the thermal effect of the separation of water from felsic melts based on data for the system albite-water: Geochemistry, v. 7, p. 637-649.

Luth, W. C., 1976, Experimental petrology: igneous rocks, in BAILEY, D. K., and MACDonald, R., eds., The Evolution of the Crystalline Rocks: New York, Academic Press, p. 333-417.

; Jahns, R. H.; and Tuttle, O. F., 1964, The granite system at pressures of 4 to $10 \mathrm{~kb}$ : Jour. Geophys. Res., v. 69, p. 759-773.

McMillan, P. F.; Jakobsson, S.; Holloway, J. R.; and Silver, L. A., 1983, A note on the Raman spectroscopy of water-bearing albite glasses: Geochim. Cosmochim. Acta, v. 47, p. 19371943.

Morse, S. A., 1970, Alkali feldspars with water at 5 kb pressure: Jour. Petrol., v. 11, p. 221-251.

Mysen, B. O., and Virgo, D., 1980, Solubility mechanisms of water in basalt melt at high pressures and temperatures: $\mathrm{NaCaAlSi}_{2} \mathrm{O}_{7}-\mathrm{H}_{2} \mathrm{O}$ as a model: Am. Mineral., v. 65, p. 1176-1184.

; Harrison, W. J.; and Scarfe, C. M., 1980, Solubility mechanisms of $\mathrm{H}_{2} \mathrm{O}$ in silicate melts at high pressures and temperatures: a Raman spectroscopic study: Am. Mineral., v. 65, p. 900-914.

Nicholls, J., 1980, A simple thermodynamic model for estimating the solubility of $\mathrm{H}_{2} \mathrm{O}$ in magmas: Contrib. Mineral. Petrol., v. 74, p. 211220 .

Nogami, M., and Tomozawa, M., 1984, Effect of stress on water diffusion in silica glass: Jour. Am. Ceram. Soc., v. 67, p. 151-154.

Ostrovskit, I. A.; Mishina, G. P.; and Povilaitis, V. M., 1959, Pressure-temperature projection of the system silica-water: Doklady Akademii Nauk SSSR (Doklady Academy of Sciences USSR), v. 126, p. 587-588.

Oхтову, W., and Hamilton, D. L., 1978, The discrete association of water with $\mathrm{Na}_{2} \mathrm{O}$ and $\mathrm{SiO}_{2}$ in
$\mathrm{NaAl}$ silicate melts: Contrib. Mineral. Petrol., v. 66, p. $185-188$.

Richet, P.; Bottinga, Y.; Denielou, L.; Petitet J. P.; and Tequi, C., 1982, Thermodynamic properties of quartz, cristobalite and amorphous $\mathrm{SiO}_{2}$ : drop calorimetry measurements between 1000 and $1800 \mathrm{~K}$ and a review from 0 to $2000 \mathrm{~K}$ : Geochim. Cosmochim. Acta, v. 46, p. 26192658.

Shaw, H. R., 1964, Theoretical solubility of $\mathrm{H}_{2} \mathrm{O}$ in silicate melts: quasi-crystalline models: Jour. Geology, v. 72, p. 601-617.

1968, Chemical states of $\mathrm{H}_{2} \mathrm{O}$ and reaction in silicate- $\mathrm{H}_{2} \mathrm{O}$ liquids and glasses: Geol. Soc. America Special Paper, v. 121, 274 p.

Skinner, B. J., 1966, Thermal expansion, in Clark, S. P., JR., ed., Handbook of Physical Constants: New York, Geol. Soc. America, p. 75-96.

Spera, F. J., 1974, A thermodynamic basis for predicting water solubilities in silicate melts and implications for the low velocity zone: Contrib. Mineral. Petrol., v. 45, p. 175-186.

Stebbins, J. F.; Carmichael, I. S. E.; and Weill, D. E., 1983, The high temperature liquid and glass heat contents and the heats of fusion of diopside, albite, sanidine, and nepheline: Am. Mineral., v. 68, p. 717-730.

Stewart, D. B., 1967, Four-phase curve in the system $\mathrm{CaAl}_{2} \mathrm{Si}_{2} \mathrm{O}_{8}-\mathrm{SiO}_{2}-\mathrm{H}_{2} \mathrm{O}$ between 1 and 10 kilobars: Schweiz Mineralogische und Petrographische Mitteilungen, v. 47, pt. 1, p. 3559.

Stolper, E. M., 1982a, The speciation of water in silicate melts: Geochim. Cosmochim. Acta, v. 46, p. 2609-2620.

$1982 b$, Water in silicate glasses: an infrared spectroscopic study: Contrib. Mineral. Petrol., v. 81, p. $1-17$.

; Silver, L. A.; and Aines, R. D., 1983, The effects of quenching rate and temperature on the speciation of water in silicate glasses (Abs.): EOS, v. 65, p. 339.

-; WAlKer, D.; HaGer, B. H.; and HaYS, J. F., 1981, Melt segregation from partially molten source regions: the importance of melt density and source region size: Jour. Geophys. Res., v. 86, p. $6261-6271$.

Toop, G. W., and SAMIs, C. S., 1962, Activities of ions in silicate melts: Trans. Metallurgical Soc. America, v. 224, p. 878-887.

Tuttle, O. F., and Bowen, N. L., 1958, Origin of granite in light of experimental studies in the system $\mathrm{KAISi}_{3} \mathrm{O}_{8}-\mathrm{NaAlSi}_{3} \mathrm{O}_{8}-\mathrm{SiO}_{2}-\mathrm{H}_{2} \mathrm{O}$ : Geol. Soc. America Mem. 74, 153 p.

—, and England, J. L., 1955, Preliminary report on the system $\mathrm{SiO}_{2}-\mathrm{H}_{2} \mathrm{O}$ : Geol. Soc. America Bull., v. 66, p. 149-152.

Voigt, D. E.; Bodnar, R. J.; and Blencoe, J. G., 1981, Water solubility in melts of alkali feldspar composition at $5 \mathrm{~kb}, 950^{\circ} \mathrm{C}$ (Abs.): EOS, v. 62, p. 428 .

WASSERBURG, G. J., 1957, The effect of $\mathrm{H}_{2} \mathrm{O}$ in silicate systems: Jour. Geology, v. 65, p. 15-23. 